\title{
Source attribution of Bornean air masses by back trajectory analysis during the OP3 project
}

\author{
N. H. Robinson ${ }^{1}$, H. M. Newton ${ }^{2}$, J. D. Allan ${ }^{1,3}$, M. Irwin ${ }^{1}$, J. F. Hamilton ${ }^{4,5}$, M. Flynn ${ }^{1}$, K. N. Bower ${ }^{1}$, \\ P. I. Williams ${ }^{1,6}$, G. Mills ${ }^{2}$, C. E. Reeves ${ }^{2}$, G. McFiggans ${ }^{1}$, and H. Coe ${ }^{1}$ \\ ${ }^{1}$ Centre for Atmospheric Science, University of Manchester, Manchester, UK \\ ${ }^{2}$ School of Environmental Sciences, University of East Anglia, Norwich, UK \\ ${ }^{3}$ National Centre for Atmospheric Science, University of Manchester, Manchester, UK \\ ${ }^{4}$ Department of Chemistry, The University of York, York, UK \\ ${ }^{5}$ National Centre for Atmospheric Science, University of York, York, UK \\ ${ }^{6}$ Facility for Groundbased Atmospheric Measurements, University of Manchester, UK
}

Received: 4 May 2011 - Published in Atmos. Chem. Phys. Discuss.: 18 May 2011

Revised: 5 September 2011 - Accepted: 13 September 2011 - Published: 16 September 2011

\begin{abstract}
Atmospheric composition affects the radiative balance of the Earth through the creation of greenhouse gases and the formation of aerosols. The latter interact with incoming solar radiation, both directly and indirectly through their effects on cloud formation and lifetime. The tropics have a major influence on incoming sunlight however the tropical atmosphere is poorly characterised, especially outside Amazonia. The origins of air masses influencing a measurement site in a protected rainforest in Borneo, South East Asia, were assessed and the likely sources of a range of trace gases and particles were determined. This was conducted by interpreting in situ measurements made at the site in the context of ECMWF backwards air mass trajectories. Two different but complementary methods were employed to interpret the data: comparison of periods classified by cluster analysis of trajectories, and inspection of the dependence of mean measured values on geographical history of trajectories. Sources of aerosol particles, carbon monoxide and halocarbons were assessed. The likely source influences include: terrestrial organic biogenic emissions; long range transport of anthropogenic emissions; biomass burning; sulphurous emissions from marine phytoplankton, with a possible contribution from volcanoes; marine production of inorganic mineral aerosol; and marine production of halocarbons. Aerosol sub- and super-saturated water affinity was found to be dependent on source (and therefore composition), with more hygroscopic aerosol and higher numbers of
\end{abstract}

Correspondence to: $\mathrm{H}$. Coe

(hugh.coe@manchester.ac.uk) cloud condensation nuclei measured in air masses of marine origin. The prevailing sector during the majority of measurements was south-easterly, which is from the direction of the coast closest to the site, with a significant influence inland from the south-west. This analysis shows that marine and terrestrial air masses have different dominant chemical sources. Comparison with the AMAZE-08 project in the Amazon basin shows Bornean composition to arise from a different, more complex mixture of sources. In particular sulphate loadings are much greater than in Amazonia which is likely to mainly be the result of the marine influence on the site. This suggests that the significant region of the tropics made up of island networks is not well represented by extrapolation from measurements made in the Amazon. In addition, it is likely that there were no periods where the site was influenced only by the rainforest, with even the most pristine inland periods showing some evidence of non-rainforest aerosol. This is in contrast to Amazonia which experienced periods dominated by rainforest emissions.

\section{Introduction}

In order to assess and predict the anthropogenic influence on climate, it is also important to understand the natural role of the biosphere. One way the biosphere can affect climate is through its role in aerosol production. This aerosol can then interact with solar radiation directly, acting to scatter shortwave radiation to space, and indirectly through its role as cloud condensation nuclei $(\mathrm{CCN})$ acting to influence cloud brightness and persistence (Denman et al., 2007).

Published by Copernicus Publications on behalf of the European Geosciences Union. 
The tropics have a large influence on global climate due to the high surface flux of solar radiation, however to date the comprehensive data needed to fully characterise the gas and aerosol composition in these environments has been scarce. The tropics contain about half the World's forests (Food and Agriculture Organisation, 2010), playing a major role in the global biosphere. This natural background is being affected by anthropogenic activity such as deforestation and land use changes. It is important to assess the extent to which anthropogenic activities are affecting tropical aerosol, and their subsequent effects on climate.

Intensive field studies have been performed in Amazonia (ACP special issue OP3/ACES: Oxidant and particle photochemical processes above a south-east Asian tropical rain forest), Martin et al., 2010; JGR special issue 107, Avissar et al., 2002) and West Africa (ACPD special issue AMMA Tropospheric Chemistry and Aerosols; Lebel et al., 2010) but until now data from South East Asia has been limited. Specifically, the AMAZE-08 project in Amazonia found that sub-micron aerosol was dominated by biogenic secondary organic aerosol (BSOA) with elevated levels of oxidised organic aerosol (OOA) and sulphate during periods influenced by out-of-basin sources, which were attributed to biomass burning transport from Africa or a marine influence (Chen et al., 2009). The major source of submicron aerosol in West Africa is from biomass burning during the dry season and BSOA during the monsoon season (Capes et al., 2009, 2008). It also experiences high sulphate loadings which may be due to the influence of the Atlantic Ocean, although data coverage and quality did not allow this to be drawn as a conclusion.

Borneo is home to one of the largest expanses of rainforest in the world making it an important part of the biosphere and a potentially large source of volatile organic compounds (VOC) and associated BSOA. There is widespread deforestation on Borneo where land is being given over to logging and, particularly, palm oil production (McMorrow and Talip, 2001), meaning the role of the biosphere in the region is changing. Global palm oil production grew by $8 \%$ per year between 1976 and 2006, with the majority of production in Malaysia and Indonesia (Carter et al., 2007). It has been shown that oil palms are a large source of isoprene in Borneo (five times more than the rainforest; Hewitt et al., 2009). Isoprene has previously been found to produce secondary organic aerosol (SOA) in chambers and field studies (Claeys et al., 2004; Surratt et al., 2006, 2008; Paulot et al., 2009; Kleindienst et al., 2009; Surratt et al., 2010; Chan et al., 2010) and is thought to produce a substantial fraction of the SOA in Borneo (Robinson et al., 2011). As Borneo is an island, marine influences could be much larger than that in Amazonia and Africa. The oceans are a source of dimethyl sulphide (DMS) produced by phytoplankton (Kloster et al., 2006), minerals contained in sea water (Millero, 1974), halocarbons (Butler et al., 2007) and OA (O’Dowd et al., 2004; Novakov et al., 1997; Facchini et al., 2008). Borneo has a population of around 16 million people, mostly inhabiting regions around the coast, so there is potential for influence of anthropogenic pollution in the form of combustion related emissions from transport, power stations or biomass burning. There is an abundance of volcanoes near Borneo which are a known source of sulphurous gases that are processed in the atmosphere to form aerosol (Pandis et al., 1995; Allen et al., 2002), which may contrast to other tropical studies that have not reported a volcanic influence (Chen et al., 2009; Capes et al., 2008).

Measurements were made as part of the Oxidant and Particulate Photochemical Processes Above a South East Asian Rainforest (OP3) project in protected rainforest in Sabah, Borneo (Hewitt et al., 2010). This region extends from around $4^{\circ} \mathrm{N}$ to the north coast of the island. Investigating the relationship between composition and synoptic flow can provide insight into significant regional sources. Two different but complementary methods employing back trajectories are used to attribute geographical sources, which can then be linked to likely emission sources. The focus of the paper is on species with a long enough atmospheric lifetime (hours or more) to be suitable for the analyses; mainly submicron aerosol composition and physical property measurements, but also long lived trace gases such as $\mathrm{CO}$ and halocarbons. Specifically the issues dealt with are the separation of atmospheric species originating on- and off-island and the attribution of likely sources.

\section{Methods}

\subsection{Instrumentation}

Measurements were performed at the Bukit Atur site $\left(4^{\circ} 58^{\prime} 49.33^{\prime \prime} \mathrm{N}, 117^{\circ} 50^{\prime} 39.05^{\prime \prime} \mathrm{E}, 426 \mathrm{~m}\right.$ a.s.1.) during two periods: 7 April-4 May (OP3-I) and 23 June-23 July (OP3III). Measurements from the intervening period (OP3-II) were made from a different measurement site and are not detailed here. An overview of measurement techniques and a description of the measurement site can be found in the OP3 overview paper, Hewitt et al. (2010). There was poor data coverage during OP3-I and, though air mass characterisations of both periods are presented in Sect. 2 for reference, results presented here focus on OP3-III.

Aerosol composition was measured using a High Resolution Aerodyne Aerosol Mass Spectrometer (AMS; DeCarlo et al., 2006; Canagaratna et al., 2007) - a state of the art instrument capable of providing detailed bulk composition and aerodynamic sizing measurements of aerosols with a time resolution of minutes. It is limited to measurements of submicron non-refractory aerosol, where non-refractory (NR) is operationally defined as a species that volatilises quickly (on time-scales of less than a second) after impaction on the tungsten vaporiser (nominally run at $600^{\circ} \mathrm{C}$ ). Conversion of AMS aerosol mass loadings into total aerosol volume (assuming organic and inorganic densities as in Cross et al., 2007) allowed for comparison with a DMPS sampling from the same 
inlet, and limited to the same size range. The instruments agreed and correlated well $(r=0.92)$ and a linear regression of AMS vs. DMPS volume series gave a gradient of 0.45 . The collection efficiency (CE) factor accounts for the likelihood that a particle will be successfully vapourised and detected once in the AMS, and has typically been found to be around 0.5 in other projects (Matthew et al., 2008). The gradient of the linear regression is consistent with this and a $\mathrm{CE}$ of 0.5 has been applied to all the AMS data.

Despite extensive fragmentation, individual peaks in the mass spectrum provide more information about aerosol composition. Insight into the photochemical age of organic aerosols (OA) can be gained from the $\mathrm{m} / \mathrm{z} 44$ (mainly $\mathrm{CO}_{2}^{+}$) to 43 (mainly $\mathrm{C}_{2} \mathrm{H}_{3} \mathrm{O}^{+}$and $\mathrm{C}_{3} \mathrm{H}_{7}^{+}$) peaks ( $\mathrm{Ng}$ et al., 2010; Jimenez et al., 2009; Morgan et al., 2010). Organic spectra with a low $f_{44}$ and high $f_{43}$ (where $f_{x}$ denotes the fraction of the organic mass at $m / z=x$ ) are less oxidised and can be thought of as semi-volatile aerosol (SV-OOA) which exist in an equilibrium between the gas and condensed phases. Aerosol with high $f_{44}$ and low $f_{43}$ are more oxidised and can be thought of as low volatility aerosol (LV-OOA) which exists mainly in the condensed phase.

In reality organic aerosol exist in a continuum between these two endpoints that can be expressed by points on a 2-D $f_{44}$ vs. $f_{43}$ space. The peak at $m / z 60$ can be used as a marker for fresh biomass burning (Alfarra et al., 2007; Capes et al., 2008), being a peak associated with levoglucosan and other anhydrous sugars which are compounds widely reported to be emitted during biomass burning (Simoneit et al., 1999; Jordan et al., 2006). It has been shown that as organic aerosol ages (with increasing $f_{44}$ and decreasing $f_{43}$ ) its mass spectral signature becomes similar and dominated by $m / z, 44$ regardless of source (McFiggans et al., 2005; Ng et al., 2010; Morgan et al., 2010).

The unit mass resolution organic aerosol data from the AMS were analysed using positive matrix factorisation (PMF). This is a multivariate technique that endeavours to explain the bulk organic AMS mass spectral time series in terms of time series of differing amounts of static "factor" spectra which can then be linked to distinct components of the ensemble organic aerosol mass (Paatero and Tapper, 1994; Paatero, 1997; Ulbrich et al., 2009). The details of the PMF analysis of the OP3 data were originally published in Robinson et al. (2011). The dependence of the solution on starting parameters (seeds) and rotational ambiguity (fpeak) was explored. In short, the most satisfactory solution was found to be the four factor solution. The results of the PMF analysis are discussed in more detail in Sect. 2.3. The high mass resolution of the AMS also enables the separation of ions at the same unit mass resolution by resolving the ion mass defects.

Subsaturated aerosol water affinity was measured as a function of size using a single column Hygroscopicity Tandem Differential Mobility Analyser (HTDMA; Cubison et al., 2005; Gysel et al., 2009), which measures the size change of an aerosol experiencing a certain change in relative humidity $(\mathrm{RH})$. This is expressed in terms of the growth factor (GF) defined as the ratio of the "dry" to "wet" size - in this case the sizes at $<15 \%$ and $90 \% \mathrm{RH}$, respectively $\left(\mathrm{GF}_{90}\right)$. The supersaturation needed to activate a particle to a cloud droplet (critical supersaturation; $\mathrm{SS}_{\text {crit }}$ ) was measured as a function of size using a Droplet Measurement Technologies dual column Cloud Condensation $\mathrm{Nu}$ cleus counter (CCNc; DMT model 100; Roberts and Nenes, 2005; Lance et al., 2006; Irwin et al., 2011, 2010; Good et al., 2010a) downstream of a differential mobility particle sizer (DMPS; Williams et al., 2000, 2007). Both the HTDMA and $\mathrm{CCNc}$ perform measurements as a function of dry $(<15 \%$ RH) aerosol size, selected using Vienna style differential mobility analysers (DMA; Winklmayr et al., 1991). The HTDMA measured at six sizes between 32 and $258 \mathrm{~nm}$ and the CCNc measured at 11 diameters between 57 and $224 \mathrm{~nm}$. Aerosol optical absorption was measured with a Thermo Scientific model 5012 Multi Angle Absorption Photometer (MAAP; Petzold and Schonlinner, 2004) which reports in black carbon equivalent loading.

The halocarbon measurements were made using gas chromatography-mass spectrometry (GC-MS). The analysis was conducted on-site at Bukit Atur. Whole air samples were dried using a Nafion contra-flow drier and were preconcentrated using a Markes International UNITY and Online Air Server with a Carbograph B and Carboxen 1000 trap. The UNITY was coupled to the Agilent 6890 GC and the MS5973 N mass spectrometer. The results presented here are from analysis on this GC-MS system in negative ion chemical ionization (NICI) mode (Worton et al., 2008). Litre samples were taken hourly (collected over a period of $40 \mathrm{~min}$ ) from a position $30 \mathrm{~m}$ up the GAW tower (Hewitt et al., 2010) and separated on a Restek RTX-502.2 column. Calibrations were performed every 8 samples using the UEA 2006 Standard reference gas which is calibrated against the "NOAA 2003" scale for $\mathrm{CHBr}_{3}, \mathrm{CH}_{2} \mathrm{Br}$ and $\mathrm{CH}_{3} \mathrm{Br}$ and the "NOAA 2004" scale for $\mathrm{CH}_{3} \mathrm{I}$ (Laboratory Earth Systems Research Global Monitoring Division, 2008). Gas phase CO measurements were made using an Aerolaser AL5002 fluorescence instrument (Gerbig et al., 1999).

\subsection{Analysis of back trajectories}

Backwards air mass trajectories (back trajectories) were generated using the British Atmospheric Data Centre Web Trajectory Service using European Centre for Medium-Range Weather Forecasts (ECMWF) wind fields (BADC, 2006a) at $1.125^{\circ} \times 1.125^{\circ}$ resolution. These trajectories show the modelled history of an air mass from a particular time and place in terms of geographical position and pressure altitude. One trajectory per hour was generated for the whole of the OP3 project - a total of 720 trajectories for OP3-I and 794 for OP3-III. Trajectories originate at the latitude and longitude 
of the ground measurement site and a pressure altitude of $950 \mathrm{hPa}$, and were calculated backwards for the preceding seven days with a $30 \mathrm{~min}$ time resolution. No trajectories impacted the surface during the time-scales investigated.

Two distinct but complementary methods were used to interpret back trajectories: construction of a map showing the dependence of the mean value of the studied quantity measured at the site on air mass residence time in specific regions; and a comparison of periods classified by cluster analysis of trajectories. These methods provide a means of separating influences of different geographical locations on measurements made from the ground site. Elevated measurement values associated with regions can in turn be attributed to likely sources. Similar approaches have been used in the past to assess sources: for example, in Mace Head, Western Ireland, Cape et al. (2000) used trajectory cluster analysis to interpret trace gas measurements and Bassford et al. (1999) used a residence time analysis to separate two discrete sources of methyl iodide - a coastal source and a sub-tropical Atlantic ocean source. The trajectory residence time analysis was pioneered by Ashbaugh (1985) who used it to attribute measurements of sulphate aerosols made in the Grand Canyon National Park to source regions. These methods are particularly useful in analysing the OP3 data as the complex local topography at the measurement site means local wind vector data are likely not to be representative of the direction of air mass origin. While ECMWF trajectories do not explicitly represent complex terrain and boundary layer processes, they should still be a good indicator of regional synoptic transport over the time scales presented here. The analyses presented are suited to analysis of species with a long atmospheric lifetime compared to the trajectory durations used, i.e. for species such as aerosol particles, carbon monoxide and halocarbons which are the focus of this paper.

Typically, of the seven day trajectories, only the $36 \mathrm{~h}$ closest to the measurement site were used, although the seven day trajectories are discussed for context in Sect. 3.1. Many of the species studied here have atmospheric lifetimes longer than this and it is possible that more insight into far field sources could be gained from their use, however we focus on shorter trajectories to minimise the introduction of erroneous analysis. This is caused by: the "shadowing" effect demonstrated in Sect. 2.2.1 below; the dependence of the density of trajectory data points on proximity to the receptor site which is inherent in the polar geometry; and the increase in the error of modelled trajectories with increased time calculated backwards.

\subsubsection{Residence time analysis of back trajectories}

The statistical method first described by Ashbaugh (1985) was extended to give an indication of geographical origins of measurements made at the ground site. For a given measurement, a geographical grid is constructed - all grids presented here used a cell size of $0.1^{\circ} \times 0.1^{\circ}$. Maps of trajectory res- idence time are shown in Fig. 1 for $36 \mathrm{~h}$ back trajectories during OP3-I and OP3-III. These are calculated by counting the number of trajectory data points in each cell for all trajectories and normalising to the probability density function inherent in the polar geometry. The polar probability density function can be calculated using

$f_{i j}(r)=\frac{1}{2 \pi R r}$

where $R$ is the limit of the radial distance from the origin of the trajectories and $r$ is the mean distance of each cell from origin of the trajectories (Ashbaugh, 1985). To assess the dependence of a measured quantity on air mass history, the value at the observing site at the time of arrival of a given trajectory is added to the grid cell that contains each trajectory point. Doing this for all trajectories and dividing by the total number of trajectory points in each cell gives the mean value measured at the ground site for an air mass that has passed over that cell. These plots are henceforth referred to as mean value maps.

Figure 2 shows an example mean value map of bromoform $\left(\mathrm{CHBr}_{3}\right)$ during OP3-III. Measurement techniques are detailed in Sect. 2.1. In interpreting mean value maps it is important to remember that air mass trajectories that regularly travel through a non-source region before travelling through a source region will show artificially elevated levels in the non-source region, henceforth called "shadowing". For example, in Fig. 2 there appears to be bromoform south of the site in the region around $1.5^{\circ} \mathrm{N}, 117^{\circ} \mathrm{E}$, however this may be artificial if the east coast is a source region. A similar argument can be made if trajectories regularly travel through a source region before travelling through a removal region (for example a region of elevated levels of precipitation acting to remove aerosol) resulting in the source region not being resolved. As a wider range of conditions are sampled, these artificial data would be expected to be of less importance with unaffected data dominating. It is also the case in general that increasing data coverage will tend to resolve sources more accurately as the influence of isolated events is outweighed by representative conditions. In order to assess the potential extent of these effects, the percentage of the entire set of calculated back trajectories that was used in the construction of each mean value map is displayed. It is also important to be able to quantify the degree of similarity between different mean value maps. This is done by calculating the Pearson's $r$ of a scatter plot of the intensities of corresponding grid points.

\subsubsection{Agglomerative hierarchical cluster analysis of back trajectories}

Trajectories were processed using the custom made cluster analysis routine described in Morgan et al. (2009) based on the method described in Cape et al. (2000). At the start of the analysis, each trajectory is assigned its own cluster. An 
(a)

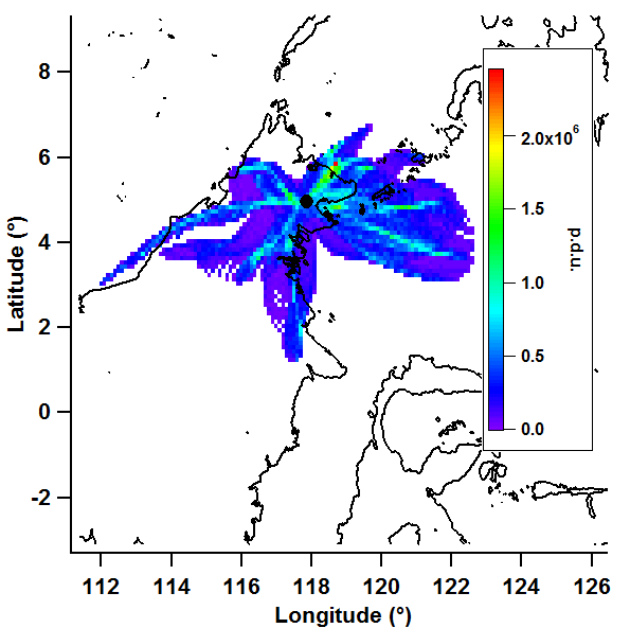

(b)

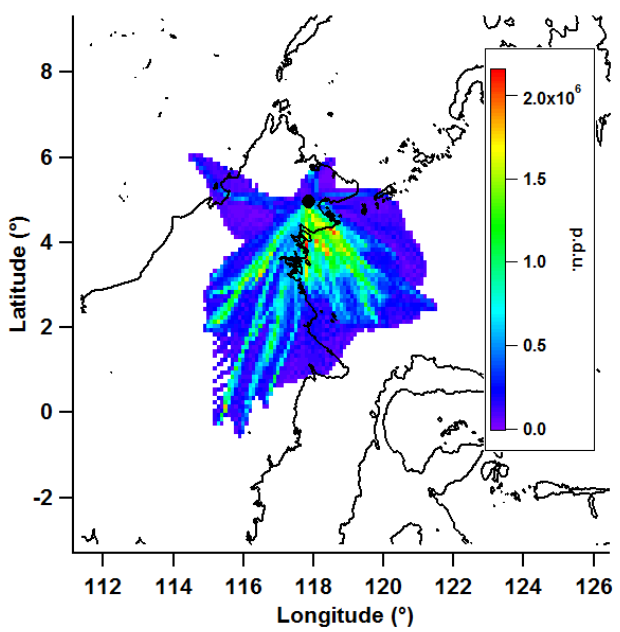

Fig. 1. Residence time of air masses in previous $36 \mathrm{~h}$ for all trajectories during (a) OP3-I and (b) OP3-III. Colour is number of trajectory data points (normalised to geometric probability density function), expressed in the resulting procedure defined units (p.d.u.). Trajectory receptor site (the measurement site) marked with a black dot.

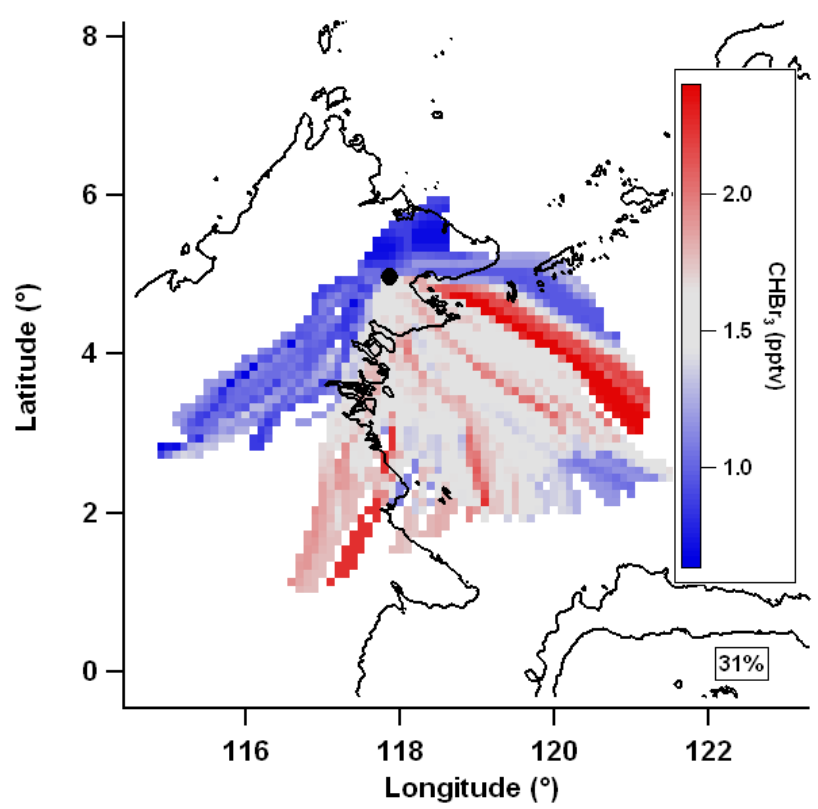

Fig. 2. Example mean value map of bromoform $\left(\mathrm{CHBr}_{3}\right)$ during OP3-III using $36 \mathrm{~h}$ trajectories. Grey is median value, red is greater than median, blue is less than median and white denotes no data coverage. Percentage of trajectories used denoted below key.

average linkage method was used based on calculating the squared distance between trajectories at each time step using

$d\left(x_{i}, x_{j}\right)=\sum_{k}\left\{\left(x_{k i}-x_{k j}\right)^{2}+\left(y_{k i}-y_{k j}\right)^{2}+\left(p_{k i}-p_{k j}\right)^{2}\right\}(2)$

where $x_{k}, y_{k}$ and $p_{k}$ are the coordinates of $x_{i}$ or $x_{j}$. At each step in the analysis the two clusters with the lowest squared distance are agglomerated. This continues until all trajectories are in one cluster. The optimum number of clusters may then be chosen, so as to maximize between cluster variance and minimize within cluster variance (Cape et al., 2000). The choice of the optimum number of clusters is subjective, however this has been shown to be the most appropriate technique for analysing meteorological trajectories (Kalkstein et al., 1987). The suitability of a solution of $N$ clusters can be assessed using several scores. An increase in the root mean squared (RMS) distance between clusters indicates that two dissimilar clusters have been agglomerated (Cape et al., 2000). A sharp decrease of the coefficient of determination $R^{2}$, defined as

$R^{2}=1-\sum_{N} \frac{(\text { within cluster variance })}{(\text { variance of all trajectories })}$

is a subjective indicator of the number of clusters to retain (Kalkstein et al., 1987). Similarly to Morgan et al. (2009) and Cape et al. (2000), an indication of the number of major clusters is defined as the number of clusters containing more than $3 \%$ of the total number of trajectories.

The project was split into a series of successive twelve hour periods. These were classified according to the clusters that their constituent trajectories belonged to, similar to Cape et al. (2000): if trajectories belonging to more than one cluster were present, the period was deemed "unclassified", otherwise it was deemed to be influenced by that cluster. This removes periods of transition between air mass cluster, leaving comparatively stable conditions and enabling comparison between measurements influenced by different clusters. Mean, median and percentiles of measured quantities were calculated for data influenced by each cluster. These cluster 
(a)

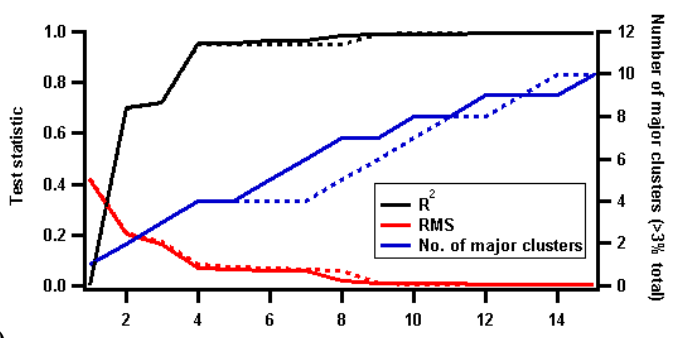

(b)

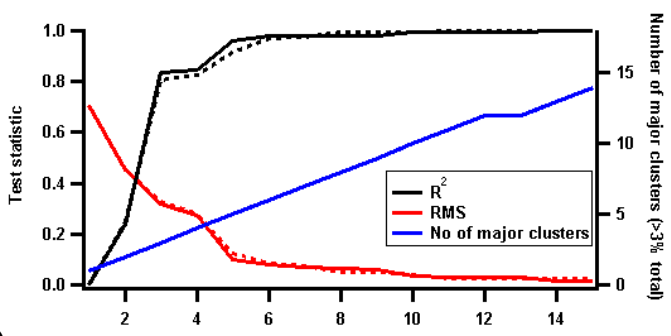

Fig. 3. $R^{2}$, RMS and number of major clusters (containing $>3 \%$ of trajectories) as a function of number of clusters in solution for (a) OP3-I and (b) OP3-III. Solid lines are for one subset of trajectories and dashed lines are for the other.

averages are discussed in Sect. 3 and presented in full in Table 4 .

In order to establish the robustness of the solution, the trajectories were split into two subsets: two day back trajectories of one hour time resolution released every two hours were used, with the alternate set similar but using trajectories from the intervening hours. The reduction in trajectory time resolution was necessary to improve computational efficiency. For both OP3-I and OP3-III, cluster scores (Fig. 3) and means (Figs. 4 and 5) show little difference between trajectory subset showing the cluster analysis solutions to be stable to perturbations, and are combined for classification and all subsequent analysis.

The scores for OP3-I (Fig. 3a) show the first major step change at the four cluster solution which is summarised in Fig. 4 and Table 1. Italics will be used for clarity when referring to cluster names, which are defined in Figs. 4 and 5. The main influence on the site is split evenly between the North-easterly, Easterly and Terrestrial clusters. Air masses associated with the Westerly cluster. Air masses associated with the Westerly cluster are of minor influence, making up only $3 \%$ of the classified periods, and can generally be disregarded.

The scores from OP3-III (Fig. 3b) show the first major step change at the five cluster solution which is summarised in Fig. 5 and Table 2. The major influence on the site was from the south-westerly Marine cluster. The Coastal cluster from the south and the Terrestrial cluster from the south-west also had significant influence. There were two more clusters; the North-easterly and Westerly but both are of minor influence (consisting of $3 \%$ and $5 \%$ of classified periods, respectively) and can generally be disregarded. Figure 10, Sect. 3.1, shows the clusters influencing the measurement site during OP3-III (displayed as a coloured bar) for comparison to the aerosol composition data.
Table 1. Details of four cluster solution and resultant period classification for OP3-I.

\begin{tabular}{lcc}
\hline Cluster name & $\begin{array}{c}\text { No. of constituent } \\
\text { trajectories (\%) }\end{array}$ & $\begin{array}{c}\text { No. of 12 h periods } \\
(\%) \text { attributed }\end{array}$ \\
\hline North-easterly & $221(31 \%)$ & $15(25 \%)$ \\
Easterly & $208(29 \%)$ & $15(25 \%)$ \\
Terrestrial & $236(33 \%)$ & $18(31 \%)$ \\
Westerly & $51(7 \%)$ & $2(3 \%)$ \\
Unclassified & & $9(15 \%)$ \\
\hline
\end{tabular}

Table 2. Details of five cluster solution and resultant period classification for OP3-III.

\begin{tabular}{lcc}
\hline Cluster name & $\begin{array}{c}\text { No. of constituent } \\
\text { trajectories (\%) }\end{array}$ & $\begin{array}{c}\text { No. of 12 h periods } \\
(\%) \text { attributed }\end{array}$ \\
\hline North-easterly & $41(5 \%)$ & $2(3 \%)$ \\
Marine & $460(58 \%)$ & $33(50 \%)$ \\
Coastal & $107(14 \%)$ & $5(8 \%)$ \\
Terrestrial & $141(18 \%)$ & $10(15 \%)$ \\
Westerly & $41(5 \%)$ & $3(5 \%)$ \\
Unclassified & & $13(20 \%)$ \\
\hline
\end{tabular}

\subsection{Positive matrix factorisation of organic aerosol mass spectra}

Different PMF solutions were explored as a function of starting conditions (seed) and rotational ambiguity (fpeak) as detailed in Robinson et al. (2011), and the most satisfactory solution was a four factor solution with fpeak $=-1$. This solution was found to have negligible dependence on starting seed. Solutions with greater than four factors were found to be unsatisfactory due to "mixing" of factors (as described in Ulbrich et al., 2009), unrealistic factor spectra consisting of one or two peaks with little signal at other $m / z$, or lack of convergence. The factor mass spectra are shown in Fig. 6 with the time series shown in Fig. 10. 
(a)

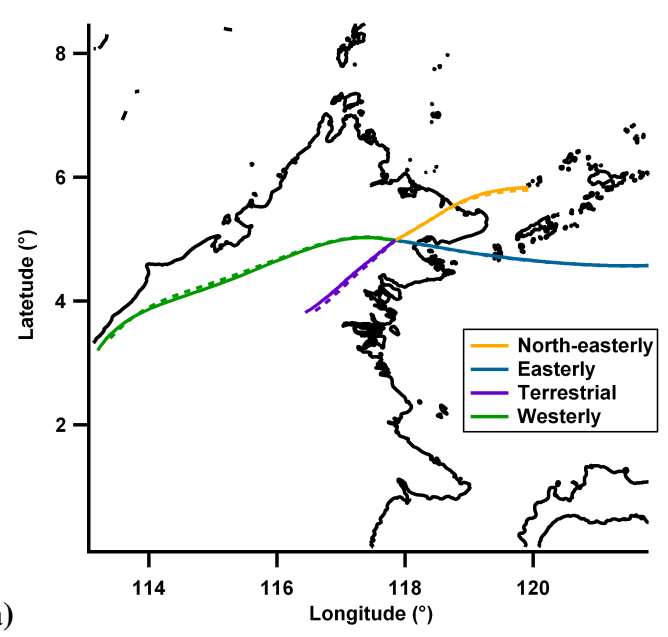

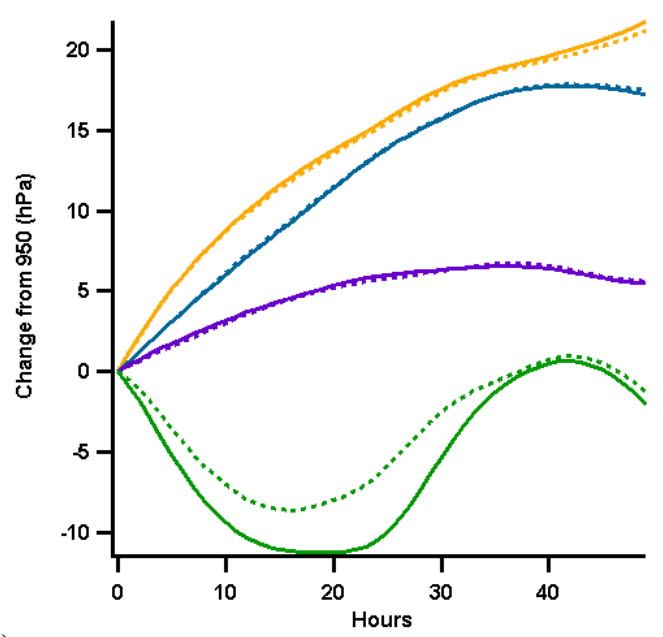

(b)

Fig. 4. OP3-I cluster mean (a) latitude and longitude and (b) pressure altitude in units of hPa different from starting altitude of $950 \mathrm{hPa}$. Colours are consistent between plots. Solid and dashed lines show solutions from each subset.
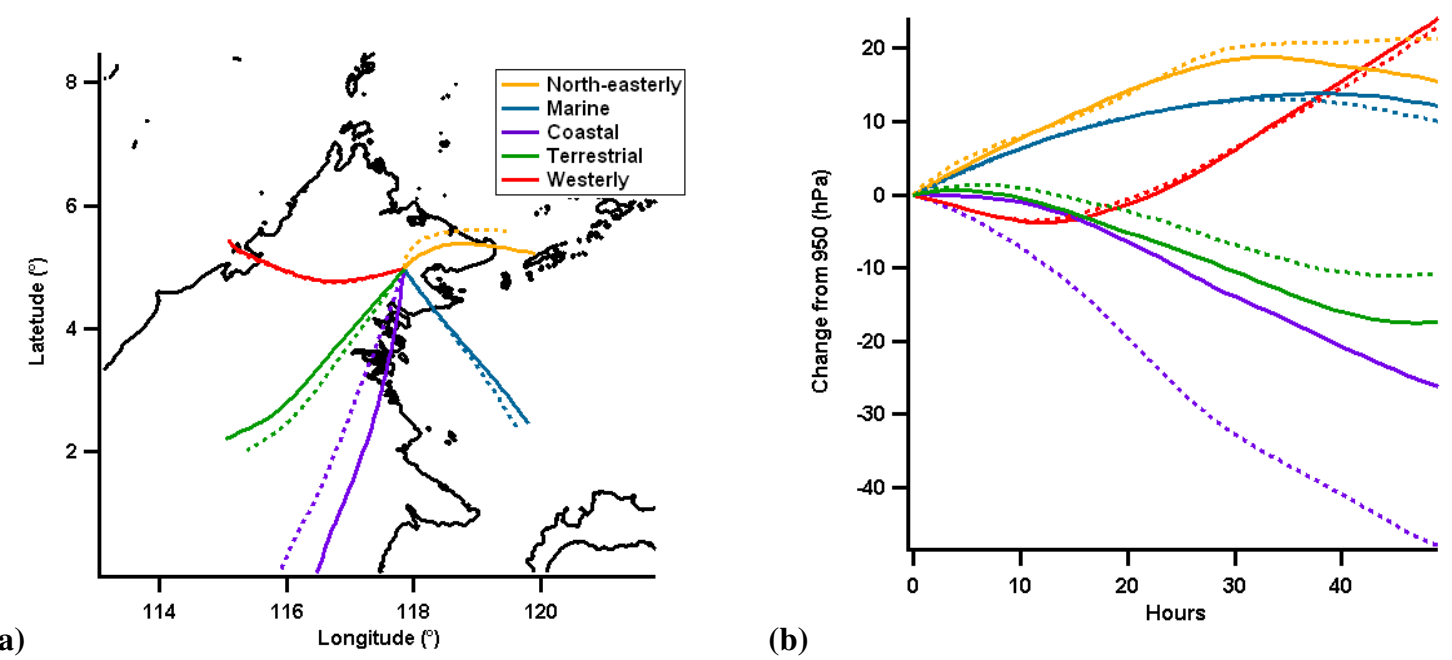

Fig. 5. OP3-III cluster mean (a) latitude and longitude and (b) pressure altitude in units of hPa different from starting altitude of $950 \mathrm{hPa}$. Colours are consistent between plots. Solid and dashed lines show solutions from each subset.

The four factors can be attributed sources from inspection of the mass spectral signature as follows. The first factor, named $91 \mathrm{Fac}$, shows some similarities to previously published mass spectra of biomass burning emissions (Alfarra et al., 2007; Allan et al., 2010) for instance a prominent $\mathrm{m} / \mathrm{z}$ 91 peak, which can be indicative of aromatic species. It does not show the $m / z, 60$ and 73 peaks normally associated with levoglucosan, an established biomass burning marker in AMS measurements (Alfarra et al., 2007). However these levoglucosan peaks have been shown to reduce with ageing of biomass burning aerosol (Capes et al., 2008), implying the 91Fac may be from far field biomass burning emissions.

The second and third factors are named OOA 1 and OOA2 respectively because of their similarity to previously pub- lished spectra (Lanz et al., 2007; Zhang et al., 2007). Spectra such as OOA1 are considered highly oxidised and have been linked to low volatility oxygenated organic aerosol (LVOOA; McFiggans et al., 2005); similarly, spectra such as OOA2 are considered less oxidised and have been linked to semi-volatile organic aerosol (SVOOA; Jimenez et al., 2009). However such assertions are impossible without a direct volatility measurement. While these factors are resolved as separate factors, they represent what are in reality different ends of a continuum of OA oxidations ( $\mathrm{Ng}$ et al., 2010; Morgan et al., 2010). OA is gradually oxidised from OOA2-like to OOA1-like aerosol over time, which would be represented by the PMF factors as a reduction in OOA2 and a concurrent increase in OOA1. 


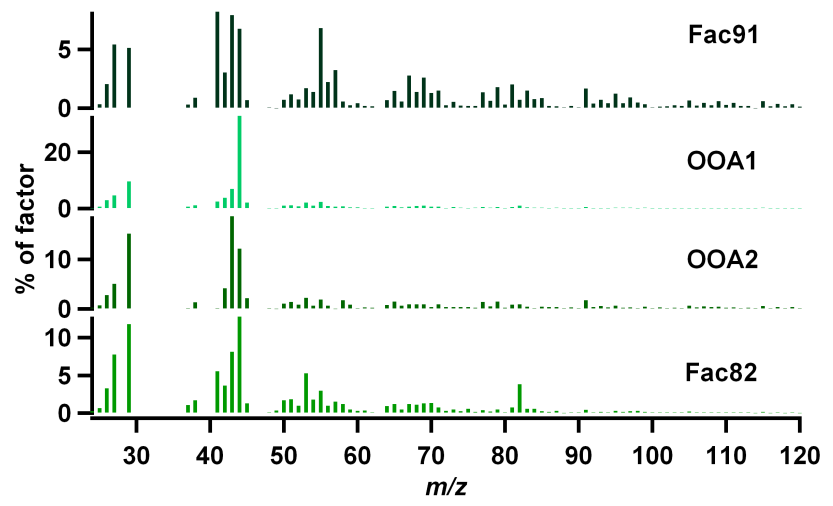

Fig. 6. Factor spectra for the four factor, fpeak $=-1$ solution of PMF analysis of organic mass spectra. From top to bottom, spectra are $91 \mathrm{Fac}$, OOA 1, OOA 2 and $82 \mathrm{Fac}$.

The last factor, named $82 \mathrm{fac}$ because of its prominent $\mathrm{m} / \mathrm{z}$ 82 peak, is not similar to any mass spectra widely reported in the literature. Its measurement during the OP3 project was reported in Robinson et al. (2011) who provide evidence that it is associated that it is the product of isoprene oxidation. A similar factor has since been reported in rural North America where it was also associated with isoprene oxidation (Slowik et al., 2011). Further investigation into the likely sources linked to these factors will be made through the analysis presented in this paper.

\section{Results}

\subsection{Overview of measurements and their regional setting}

The major cities in Borneo are all located on the coast, with the biggest settlements on the south west of the island. The interior of Borneo is a mountainous unsettled and undeveloped region of rainforest. Average daily large scale precipitation from the ECMWF Integrated Forecasting System model reanalysis shows increased precipitation in the interior of Borneo (Fig. 7; BADC, 2006b). It is likely that this increased precipitation is due to the orography inland. Precipitation inhibits long range transport of aerosol. This means air masses from the southwest of the site will tend to have reduced concentrations of background aerosol. These air masses will have relatively greater amounts of locally produced aerosol.

Figure 8 shows a trajectory residence time plot, and the average minimum pressure (maximum altitude) of the trajectories passing through each cell, both using seven day back trajectories. These provide context for the more detailed analyses presented herein which use shorter $(36 \mathrm{~h})$ trajectories. This means the more detailed analyses only use trajectory data from relatively close to the receptor site where they are

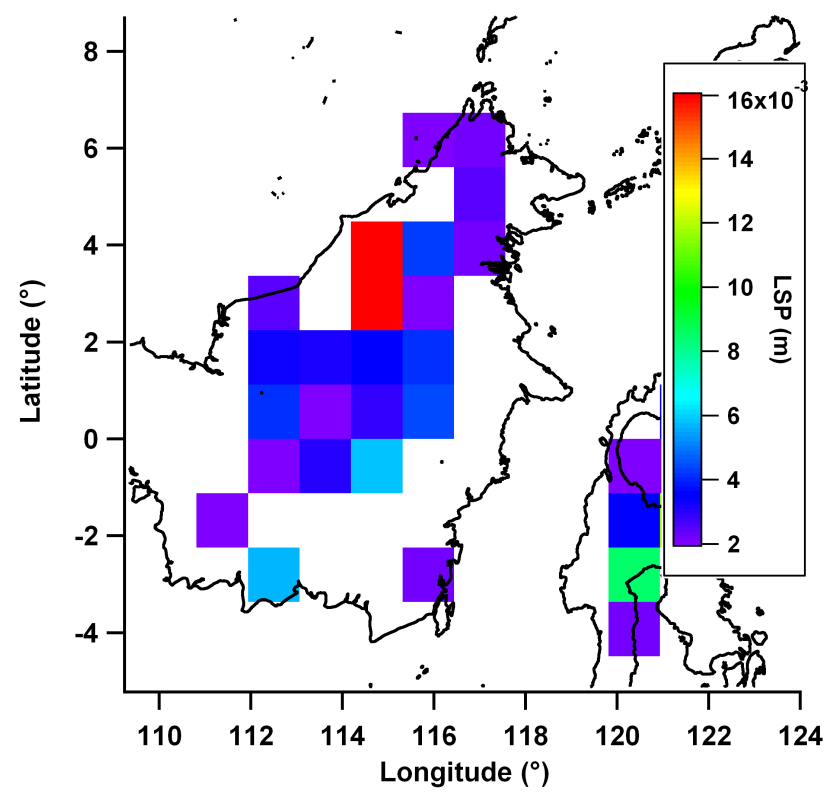

Fig. 7. Average daily large scale precipitation (m) from the European Centre for Medium-Range Weather Forecast Integrated Forecasting System model reanalysis (BADC, 2006b) at $1.125^{\circ} \times$ $1.125^{\circ}$ resolution during OP3-III. Values below $2 \times 10^{-3} \mathrm{~m}$ are not shown for clarity.

most accurate and their density is highest. The residence time plot shows that the site is mostly influenced by air masses from the south east. There is no influence from the major urbanised regional areas in mainland Malaysia (around Kuala Lumpur, east of Borneo), Singapore (south west of Borneo) and Indonesia (around Jakarta, south west of Borneo). Many air masses travel over Sulawesi (around $2^{\circ} \mathrm{S}, 121^{\circ} \mathrm{E}$ ). The majority of the 16 million people inhabiting Sulawesi live at the far south. The plot showing the average minimum pressure of trajectories passing over each cell shows trajectories travelling over the island to generally be from a greater maximum altitude than trajectories transported from the east coast of Borneo. The distribution of trajectory minimum pressures has a mean of $909 \mathrm{hPa}$, median of $938 \mathrm{hPa}$ and a tenth percentile value of $821 \mathrm{hPa}$. This corresponds to a ninetieth percentile maximum altitude of approximately $1.8 \mathrm{~km}$ a.s.l. with the majority of trajectories having a maximum altitude close to that of the receptor site.

The Moderate Resolution Imaging Spectroradiometer (MODIS) fire count (Davies et al., 2009; Justice et al., 2002; Giglio, 2003) shows hotspots/open fires detected in the wider region during OP3-III in Fig. 9. The majority of fires are concentrated to the south west of the measurement site in Vietnam, mainland Malaysia, Sumatera, Indonesia and South Western Borneo. The seven day trajectories show none of these regions to be an influence on the measurement site. The trajectories that travel up from the south of the island (largely associated with the Terrestrial and Coastal clusters) are likely 


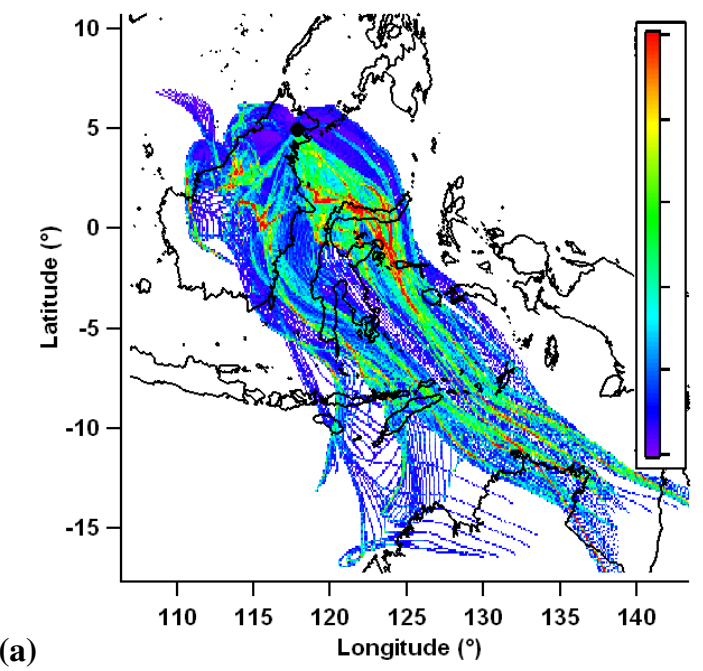

(b)

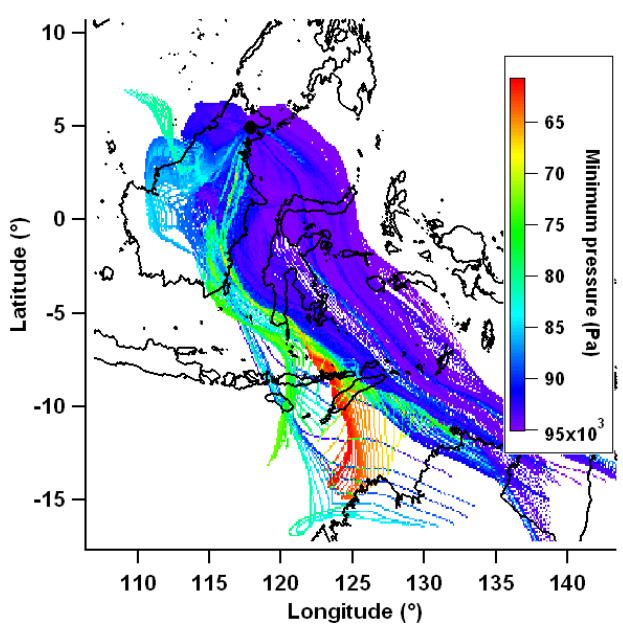

Fig. 8. (a) Residence time of air masses in previous $7 \mathrm{~d}$ for all trajectories during OP3-III. Colour is number of trajectory data points (normalised to geometric probability density function). (b) mean minimum pressure of trajectories passing through that cell in in previous $7 \mathrm{~d}$. Trajectory receptor site (the measurement site) marked with a black dot.

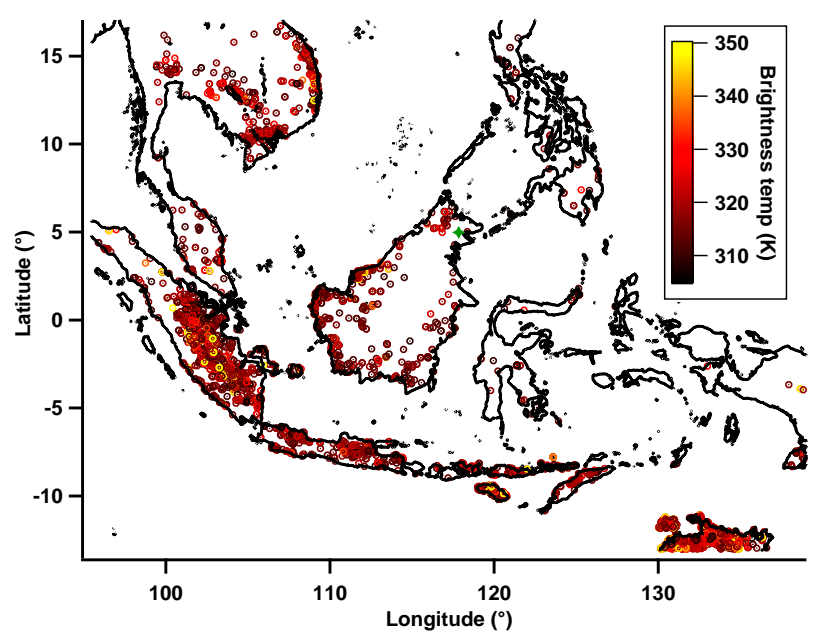

Fig. 9. MODIS hotspot/active fires coloured by temperature of event during OP3-III. Site marked with green star.

to have the most biomass burning influence due to on-island fires, and perhaps fires further afield on the Lesser Sunda Islands in South East Indonesia (around $7^{\circ} \mathrm{S}$ by $125^{\circ} \mathrm{E}$ ).

Aerosol measurements made in Borneo show a contrasting situation to Amazonia with much higher sulphate and ammonium loadings, much more similar to those measured in West Africa (Table 3). The time series of aerosol composition is shown in Fig. 10 with a bar indicating the classification of the air mass (see Sect. 2.2.2) influencing the measurement site.

\subsection{Halocarbons}

The bromoform (shown previously in Fig. 2) and dibromomethane $\left(\mathrm{CH}_{2} \mathrm{Br}_{2}\right.$; not shown $)$ mean value maps show very similar profiles $(r=0.90)$ which is unsurprising as these compounds are well correlated in the atmosphere (Butler et al., 2007; Yokouchi et al., 2005; Zhou et al., 2008). The time series collected at Bukit Atur also confirms this as their time series are well correlated. Bromoform and dibromomethane show elevated levels over coastal and marine regions compared to terrestrial regions, this is consistent with other studies which have shown them to be produced by macro-algae (Carpenter and Liss, 2000; Goodwin et al., 1997; Quack et al., 2007). In particular the south-east coast of Sabah is a region of seaweed cultivation which is reflected in the high concentration seen in air masses from this region.

The methyl iodide mean value map (Fig. 11a) is similar to those of the polybrominated compounds, however, there are some differences in features (mean value map correlations of $r=0.70$ with bromoform and with dibromomethane). Like the polybrominated compounds, the methyl iodide map shows high values to be predominantly attributable to offisland sources. This is consistent with whole air samples collected in the boundary layer during the OP3 flight campaign on the FAAM BAe-146 aircraft (Hewitt et al., 2009; Newton et al., 2011), and analysed on the same GC-MS system set-up as described in Sect. 2.1 of this paper. Data from this aircraft campaign showed a clear concentration gradient from seato-land, with highest concentrations of methyl iodide seen off the south-east coast of Sabah. The pattern of high values seen over the sea in the methyl iodide mean value map is similar to that seen in the polybrominated compound mean 


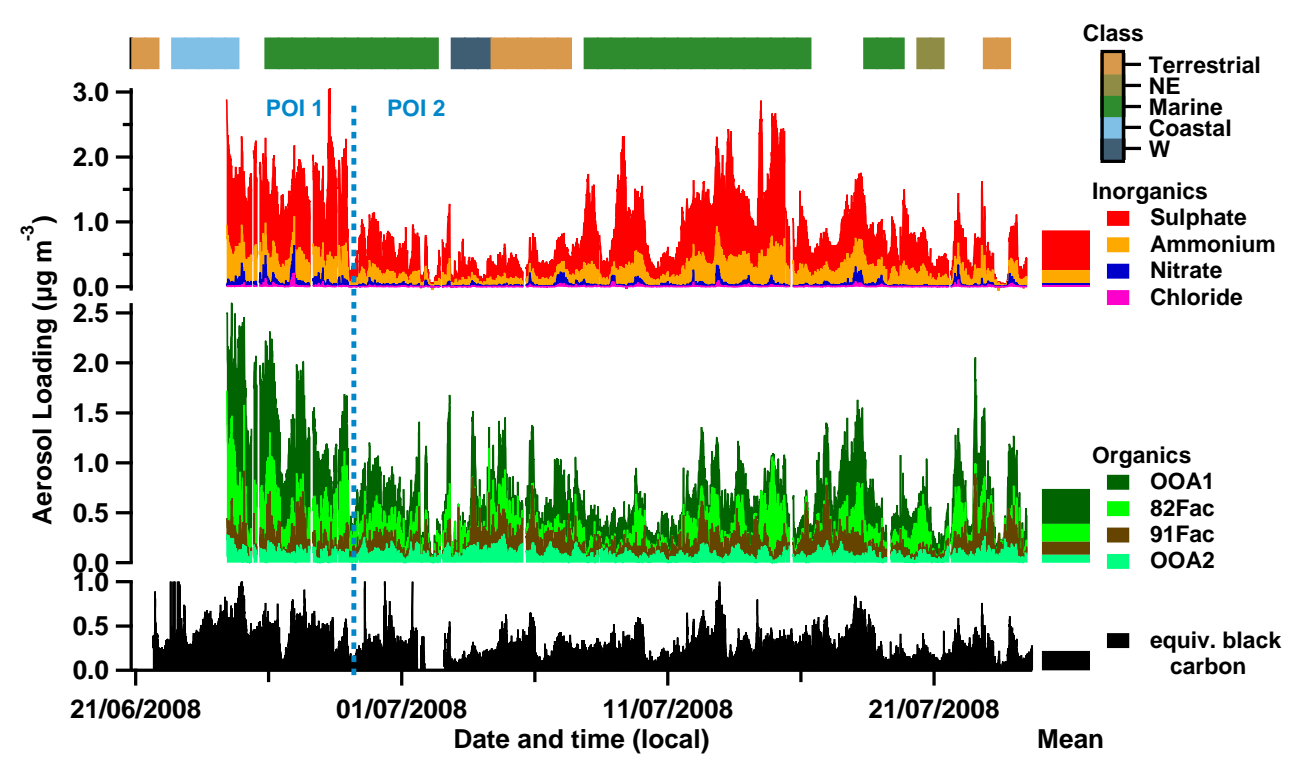

Fig. 10. Stacked time series of total sub-micron non-refractory aerosol split by composition (see Sect. 2.1) for OP3-III. The inorganics and organics are shown on separate axes, with the organics split into their constituent PMF factors. The split point between Period Of Interest (POI) One and Two is marked with a dashed blue line (see Sect. 3.6). The campaign mean aerosol loadings are shown as stacked bars to the right of the time series. Colour of bar at top indicates class of air mass influencing site (see Sect. 2). No bar indicates unclassified (changeable) air mass.

value maps. In particular the methyl iodide and polybrominated mean value maps all show a region of high values off the coast to the immediate east of Bukit Atur which extends east (to around $4^{\circ} \mathrm{N}, 120^{\circ} \mathrm{E}$ ). This shared feature suggests a co-located source of methyl iodide and the polybrominated compounds; possibly it is even the same source, potentially macro algae, which have been shown to produce all three of these compounds (Carpenter and Liss, 2000; Manley et al., 1992). Other studies have observed correlations between methyl iodide and these polybrominated compounds, but noted the inconsistency of their correlation, suggesting different production mechanisms for the methyl iodide and polybrominated compounds (Butler et al., 2007). Methyl iodide shows less separation between terrestrial and marine air masses than the polybrominated compounds. This consistent with previous studies, which have shown methyl iodide to have a mixture of marine and terrestrial sources (Bell et al., 2002; Smythe-Wright et al., 2006; Sive et al., 2007) and be emitted during biomass burning (Cox et al., 2005; Mead et al., 2008).

In stark contrast to the other three halocarbons presented here the waters immediately east of Bukit Atur around $4^{\circ} \mathrm{N}$, $120^{\circ} \mathrm{E}$ do not appear to be a productive region for methyl bromide (Fig. 11b). There is some marine contribution, predominantly from the coastal zone south of Sabah included in the extent of these maps, which is consistent with known marine sources of methyl bromide such as macro algae (Baker, 2001; Cox et al., 2005). Higher values (8-9 pptv) are seen over an area to the north of Bukit Atur $\left(5.4-6^{\circ} \mathrm{N}\right)$ covering
Table 3. Comparison of sub-micron non-refractory aerosol loadings $\left(\mu \mathrm{g} \mathrm{m}^{-3}\right)$ from different tropical campaigns. Bornean and Amazonian (Chen et al., 2009) measurements are campaign averages of ground site intensives. West African measurements are averages of low altitude data over several flights, screened to remove (local) biomass burning and anthropogenic influence (Capes et al., 2008, 2009).

\begin{tabular}{lccc}
\hline & Borneo & Amazonia & West Africa \\
\hline Organic & 0.74 & 0.64 & 1.01 \\
Sulphate & 0.61 & 0.15 & 0.82 \\
Ammonium & 0.21 & 0.02 & 0.36 \\
Total & 1.6 & 0.82 & 2.26 \\
\hline
\end{tabular}

both land and coastal areas. This area is known to comprise oil palm plantations and there are similarities between the methyl bromide mean value map and 82Fac (Fig. 14a) discussed in Sect. 3.4 although overall correlation is not high $(r=0.32)$. It is currently unknown whether oil palm trees are actually a source of methyl bromide. However, other activities associated with the oil palm plantations such as biomass burning, a known source of methyl bromide (Mead et al., 2008; Reeves, 2003), may also contribute to the localised high values. Moreover, a coastal source cannot be discounted as responsible for this feature, possibly a macro algae source. The mean value plot for methyl bromide shows an elevated feature to the south west of the measurement site, 


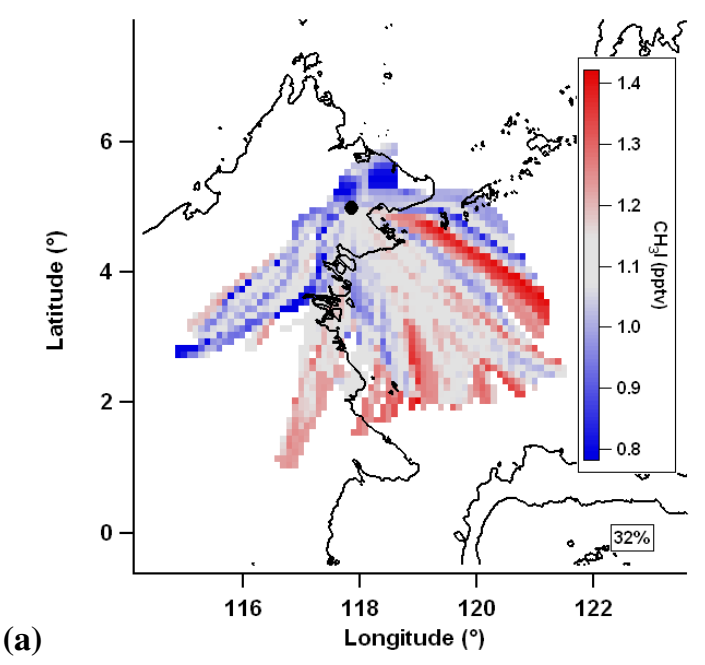

(b)

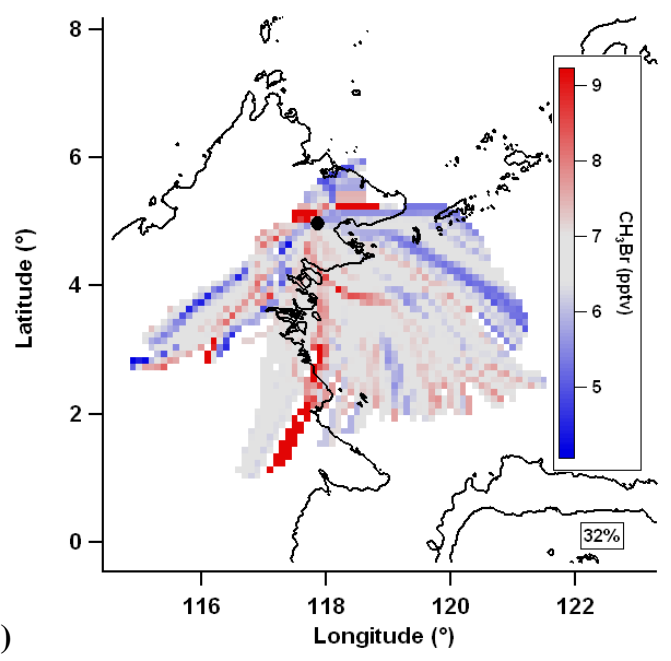

Fig. 11. Mean value maps for (a) methyl iodide, $\mathrm{CH}_{3} \mathrm{I}$ and (b) methyl bromide $\mathrm{CH}_{3} \mathrm{Br}$. Grey is median value, red is greater than median, blue is less than median and white denotes no data coverage. $36 \mathrm{~h}$ trajectories used.

in a similar location to that seen in the methyl iodide map though the exact grid boxes differ. As discussed earlier small scale biomass burning may be a contributing factor to this feature, in addition tropical vegetation has been suggested as a weak source of methyl bromide (Blei et al., 2010).

\subsection{Nitrate and chloride aerosol}

The nitrate (Fig. 12) and chloride (not shown) mean value maps and time series are similar $(r=0.76)$ suggesting the two species may be components of the same aerosol. The greatest aerosol loadings are mostly associated with marine air from the south-east. Elevated loadings shown to the far south over the Sangkulirang Peninsula (around $1^{\circ} \mathrm{N}$, $\left.117.5^{\circ} \mathrm{E}\right)$ may be artificial, caused by the preceding or subsequent transit of the air mass over the sea. Cluster averages show nitrate and chloride to be associated with air of marine origin, with greater loadings in the Marine cluster than the Terrestrial. Campaign average loadings of nitrate $\left(0.03 \mu \mathrm{g} \mathrm{m}^{-3}\right)$ and chloride $\left(0.01 \mu \mathrm{g} \mathrm{m}^{-3}\right)$ are very low however they are high when compared to Amazonia $\left(0.01 \mu \mathrm{g} \mathrm{m}^{-3}\right.$ and $0.00 \mu \mathrm{g} \mathrm{m}^{-3}$, respectively). The diurnal profile of nitrate and chloride loadings shows them to be strongly elevated around midnight with low levels throughout the day.

Nitrate $\left(\mathrm{NO}_{3}^{-}\right)$is produced in the atmosphere by oxidation of $\mathrm{NO}_{\mathrm{x}}$ on the time-scale of hours. Hewitt et al. (2009) found that $\mathrm{NO}_{\mathrm{x}}$ levels in Borneo, while typically lower than those found in more developed countries such as USA and Europe, were highest over the oil palm plantations where the sources were vehicle emissions, combustion and crop fertilisation. The AMS nitrate loading is derived from two fragments $\left(\mathrm{NO}^{+}\right.$and $\mathrm{NO}_{2}^{+}$at $\mathrm{m} / \mathrm{z}, 30$ and 46$)$ and during $\mathrm{OP} 3$ these varied, indicating that the nitrate that is detected is unlikely to be purely in the form ammonium nitrate $\left(\mathrm{NH}_{4} \mathrm{NO}_{3}\right)$, as this is

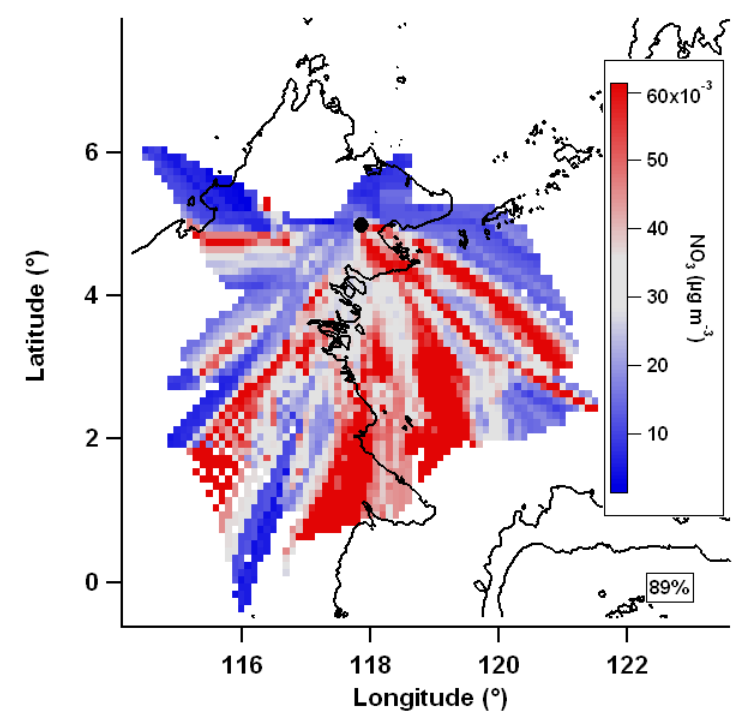

Fig. 12. Mean value map for nitrate. Grey is median value, red is greater than median, blue is less than median and white denotes no data coverage. $36 \mathrm{~h}$ trajectories are used.

known to fragment consistently. The ratio of the mean ambient $\mathrm{NO}^{+}$and $\mathrm{NO}_{2}^{+}$signals is significantly greater than during calibrations using ammonium nitrate (5.4 vs. 2.6). The AMS has been shown to be poor at measuring organic nitrates directly as $\mathrm{C}_{\mathrm{x}} \mathrm{H}_{\mathrm{y}} \mathrm{N}^{+}$or $\mathrm{C}_{\mathrm{x}} \mathrm{H}_{\mathrm{y}} \mathrm{O}_{\mathrm{z}} \mathrm{N}^{+}$(Farmer et al., 2010), with significant mass $(30 \%)$ detected at the $\mathrm{NO}_{\mathrm{x}}^{+}$peaks (Rollins et al., 2010), which make up AMS "nitrate" measurements usually associated with inorganic nitrate. However the majority of organic nitrate mass is still thought to be measured at the $\mathrm{C}_{\mathrm{x}} \mathrm{H}_{\mathrm{y}} \mathrm{N}^{+}$and $\mathrm{C}_{\mathrm{x}} \mathrm{H}_{\mathrm{y}} \mathrm{O}_{\mathrm{z}} \mathrm{N}^{+}$peaks (Rollins et al., 2010) and there is little correlation of these signals with the $\mathrm{NO}^{+}$ 
and $\mathrm{NO}_{2}^{+}(r=0.29)$, implying any role of organic nitrates to be low.

A likely source of chloride containing aerosol is sodium chloride particles from sea water, however the AMS cannot measure sea salt particles well as they are usually too large to be successfully sampled and they vapourise slowly (Allan et al., 2004). There is no excess ammonium $\left(\mathrm{NH}_{4}\right)$ detected after the neutralisation of sulphate in Borneo, meaning nitric acid will not readily be neutralised. The introduction of nitric acid $\left(\mathrm{HNO}_{3}\right)$ to aqueous sodium chloride particles would force the chloride to partition to the gas phase in the form of hydrogen chloride $(\mathrm{HCl})$. This leads to aqueous sodium nitrate particles that are more easily volatilised by the AMS. The liberated hydrogen chloride can then react to form aerosol which is detected by the AMS. While there are no direct measurements of the composition of the chloride containing aerosol, it is likely that they are in the form ammonium chloride.

The nitrate and chloride diurnal profiles show a very strong increase at night, which may be driven by partitioning of vapours as the temperature reduces. A dense layer of fog formed across the forest every night which may have facilitated nitrate and chloride aerosol reformation occurring in the aqueous phase. Furthermore, the measurement site, located on a ridge top, protruded above the planetary boundary layer top every night (Pearson et al., 2010) which may have introduced more marine influenced aerosol that would be typical of the regional background.

\subsection{Organic aerosol}

The OOA1 mean value map shows both off-island and onisland sources (Fig. 13a). The Marine and Terrestrial period averages $\left(0.33\right.$ and $0.29 \mu \mathrm{g} \mathrm{m}^{-3}$, respectively) show, while both sources are significant, the off island source is larger. The greatest concentrations of OOA1 are in marine/coastal air masses. These are likely to be the result of long range transport of highly oxidised regional emissions with a possible contribution from processed biomass burning at the start of the measurement period (see Sect. 3.6). It is likely that the on island source of OOA1 represents the aged component of BSOA from the rainforest and the components of regional long range transport aerosol that is not removed through wet deposition during transit across the island. The inland OOA1 is changeable, showing both high and low loadings, and it is conceivable that the amount of inland OOA1 is driven by the level of precipitation inland.

The OOA2 mean value map (Fig. 13b) shows a strongly terrestrial source of aerosol, with Marine and Terrestrial period loadings of 0.11 and $0.07 \mu \mathrm{g} \mathrm{m}^{-3}$, respectively. It shows elevated loadings across much of the island with the exception of the known oil palms to the immediate north and south of the measurement site. This suggests the rainforest is a source of freshly produced BSOA from the oxidation of rainforest VOC emissions which are represented by the OOA2 factor. OOA2 is a relatively minor fraction of the total organic aerosol, making up only $11 \%$ compared to OOA1 which makes up $47 \%$. This is expected in an environment such as Borneo where there are influences from far field sources such as off-island anthropogenic sources and $\mathrm{OA}$ from oceanic emissions, meaning more aged organic aerosol could dominate.

The ratio of mean value maps of OOA1 to OOA2 (extent of oxidation; Fig. 13) shows the oxidised aerosol to be originating externally to the island compared to the less oxidised aerosol which originates in the island interior. This implies the highly oxidised OA is from long range transport of aerosols that are emitted from sources external to the island, either biogenic or anthropogenic. Figure 13 shows low OA oxidation in air masses travelling across the centre of the island, a region of enhanced precipitation (Fig. 7). Wet removal of aerosol is likely to lead to depleted concentrations of regional aerosol (highly aged OA) and relatively increased concentrations of more locally produced aerosol. This local aerosol is likely to be BSOA generated from rainforest produced precursors as there were not any other major sources known to be nearby (e.g. biomass burning, large settlements), especially in the inland region.

The oil palm plantations in Borneo have been shown to be a substantial source of isoprene, with emissions per unit area five times higher than the rainforest (Hewitt et al., 2009). Robinson et al. (2011) showed that isoprene was a significant source of BSOA at the measurement site in Bukit Atur, linking isoprene derived BSOA to a distinctive $\mathrm{m} / \mathrm{z} 82$ peak in the AMS organic aerosol mass spectrum and the associated 82Fac PMF factor. The mean value map of $82 \mathrm{Fac}$ (Fig. 14a) shows higher than average loadings in air masses from the immediate north, north-east and south-east. These are all areas of oil palm agriculture, as shown in Fig. 1b of Hewitt et al. (2010). The air masses associated with these areas also have particularly low maximum altitudes meaning they are likely to be particularly influence by local surface emissions (Fig. 8). The cluster averages show higher 82Fac loadings from air masses associated with the Marine cluster than Terrestrial ( 0.18 vs. $0.12 \mu \mathrm{g} \mathrm{m}^{-3}$, respectively), which in this case corresponds to air masses from the Semporna Peninsula region to the immediate south-east of the site (approximately $4.5^{\circ} \mathrm{N}, 118^{\circ} \mathrm{E}$ ). The north-easterly cluster, which corresponds to air mass from the oil palms to the north, shows high average loadings $\left(0.14 \mu \mathrm{g} \mathrm{m}^{-3}\right)$, although there is a low amount of data from this period as stated earlier. Loadings are periodically high across the rest of the island signifying additional inland sources. The $82 \mathrm{Fac}$ OA makes up a significant proportion of the total OA (24\%). Robinson et al. (2011) speculated that the formation of isoprene SOA may be catalysed by the high sulphate loadings in Borneo: acidic sulphate has been shown to affect isoprene SOA formation in chambers (although through a mechanism unlikely to yield the $m / z, 82$ marker detected in Borneo; Surratt et al., 2010) and acidic aerosol has been shown to catalyse the 
(a)

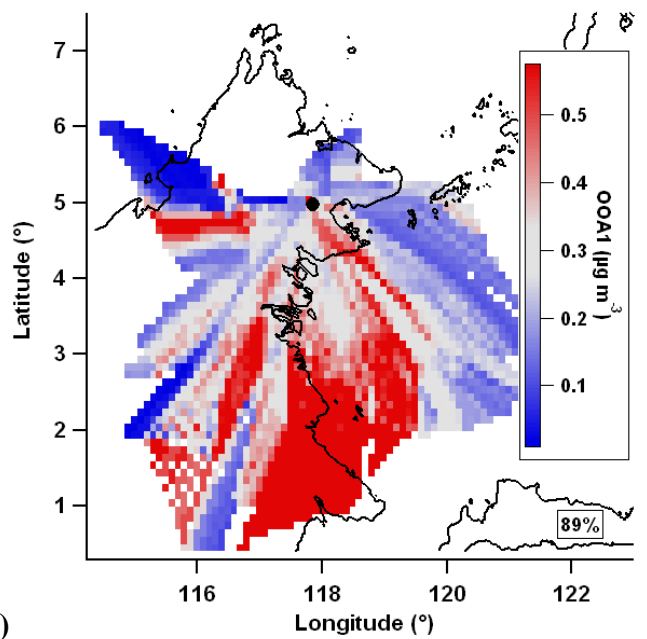

(b)

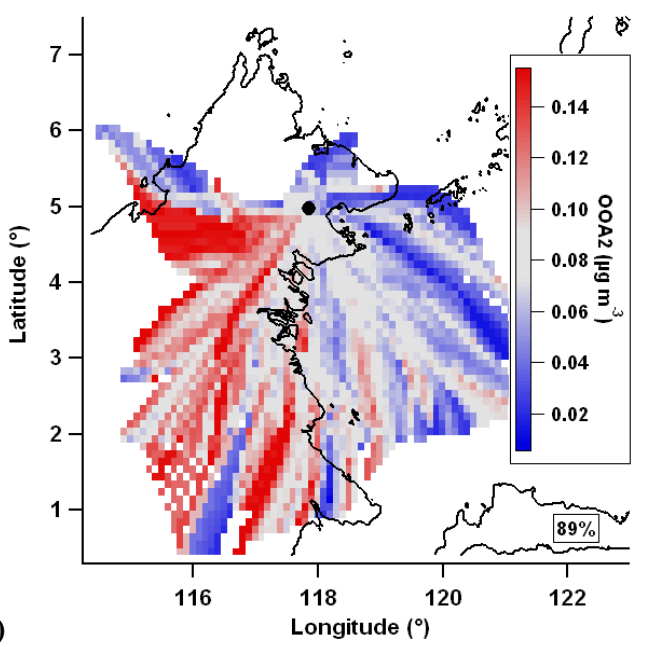

(c)

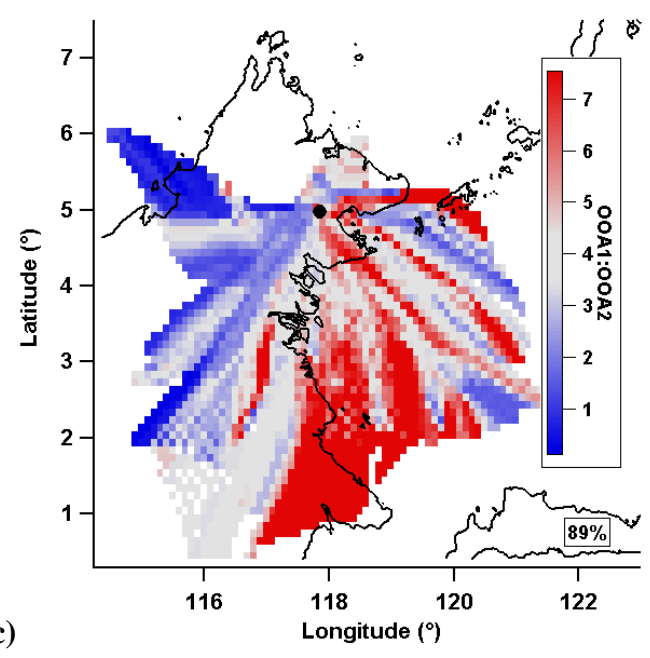

Fig. 13. (a) OOA1, (b) OOA2 and (c) the ratio of the OOA1 and OOA2 mean value maps, equivalent to OA oxidation. Grey is median value, red is greater than median, blue is less than median and white denotes no data coverage. $36 \mathrm{~h}$ trajectories are used.

heterogeneous reactive uptake of 1,4-hydroxycarbonyls (established isoprene oxidation products) to condensed phase species likely to yield the $\mathrm{m} / z 82$ peak (Lim and Ziemann, 2009). The mean value map of excess sulphate (Fig. 14) shows the main source to the south-east of the site, in one of the regions associated with isoprene SOA. It should be noted that sulphate aerosol that is neutralised by the time of arrival at the measurement may be acidic closer to the coast where it has had less time to be neutralised by terrestrial ammonium sources.

\subsection{Sulphate aerosol}

The mean value map correlation $(r=0.93)$ suggests that sulphate (Fig. 15) and ammonium are components of the same aerosol, with the ion balance indicating this is likely in the form of ammonium sulphate. Cluster averages of ammonium and sulphate show greater loadings in the Marine cluster than in the Terrestrial cluster ( 0.25 vs. $0.09 \mu \mathrm{g} \mathrm{m}^{-3}$ for ammonium and 0.75 vs. $0.25 \mu \mathrm{g} \mathrm{m}^{-3}$ for sulphate, respectively), which is consistent with the mean value maps.

Ammonia is produced from the natural breakdown of urea and uric acid excretion from animals and emissions from fertiliser. It is the primary basic gas in the atmosphere and would be expected to be present in Borneo. Sulphate aerosol is often produced from processing of anthropogenic emissions of $\mathrm{SO}_{2}$ from fossil fuel combustion. South East Asia uses more sulphur rich vehicle fuel (International Fuel Quality Center, 2009) than western countries meaning anthropogenic fossil fuel combustion may be of particular influence in the region. Sulphate is also produced naturally by processing of phytoplankton DMS emission (Kloster et al., 2006) and gaseous sulphur emitted by volcanoes (Allen et al., 2002). Previous studies have used the methane sulphonic 


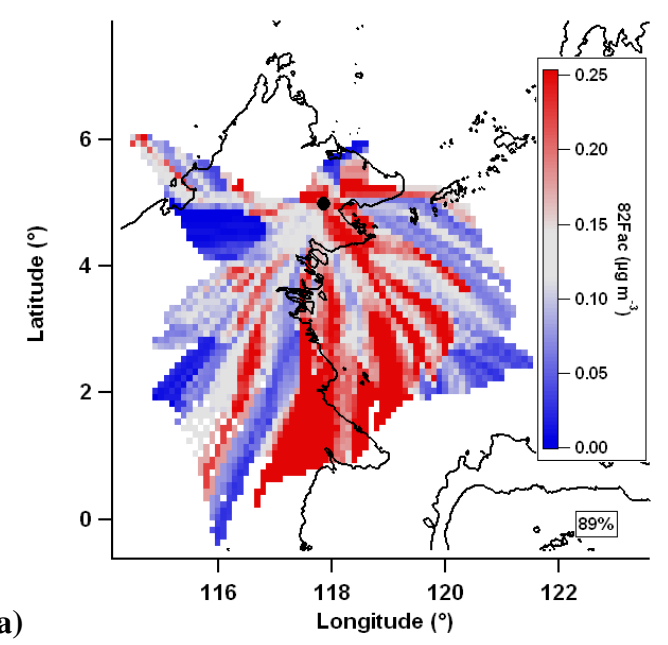

(b)

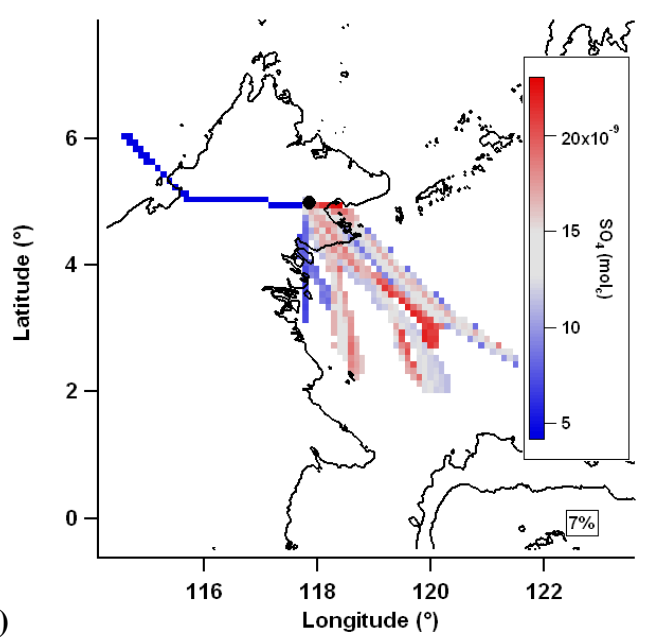

Fig. 14. Mean value maps of (a) $82 \mathrm{Fac}$ and (b) excess sulphate (defined as moles of charge of sulphate greater than moles of charge of ammonium plus $3 \times 10^{-9}$ to account for spread of neutral values). Grey is median value, red is greater than median, blue is less than median and white denotes no data coverage. $36 \mathrm{~h}$ trajectories are used.

acid peak (MSA; $\mathrm{CH}_{3} \mathrm{SO}_{3} \mathrm{H}$ ) of the high resolution AMS mass spectrum as a marker for DMS derived sulphate aerosol (Zorn et al., 2008). The yield of MSA relative to sulphate from atmospheric DMS oxidation has been shown to be much lower in tropical conditions (Bates et al., 1992; Allan et al., 2009) and no MSA signal was apparent in the Borneo dataset.

Volcanic activity was reported around the time of the OP3 project from Ruang (735 m), an island north of Sulawesi, Indonesia, East of Borneo and Mount Papandayan (2665 m) on Java, Indonesia, to the South of Borneo (Venzke et al., 2010), and could be responsible for some of the sulphate aerosol detected. However, if the back trajectories are assumed to be reliable when extended to the seven day limit (Fig. 8), these regions did not influence the site.

A scatter plot of sulphate loading vs. OA loading, coloured by cluster, is shown in Fig. 16, similar to the method used in Chen et al. (2009) when analysing aerosol composition in Amazonia. Figure S1 of the Supplement shows the same scatter plot coloured by $\mathrm{m} / \mathrm{z}$ 44:43 (OA oxidation). Lines indicate the modal centres of the histogram of values of the sulphate to OA ratio. It should be noted that some level of correlation is to be expected between aerosol loadings due to shared removal processes, hence points at all three lines show a degree of correlation. Line A indicates points of high sulphate concentration with little dependence on OA loading, which are characteristically associated with the Marine cluster. They also show a varied level of OA oxidation. They are consistent with sources of sulphate external to Borneo that are not necessarily associated with production of OA - such as marine DMS production or volcanic emissions.

Line B indicates points of correlated high sulphate and OA concentration which are characteristically associated with

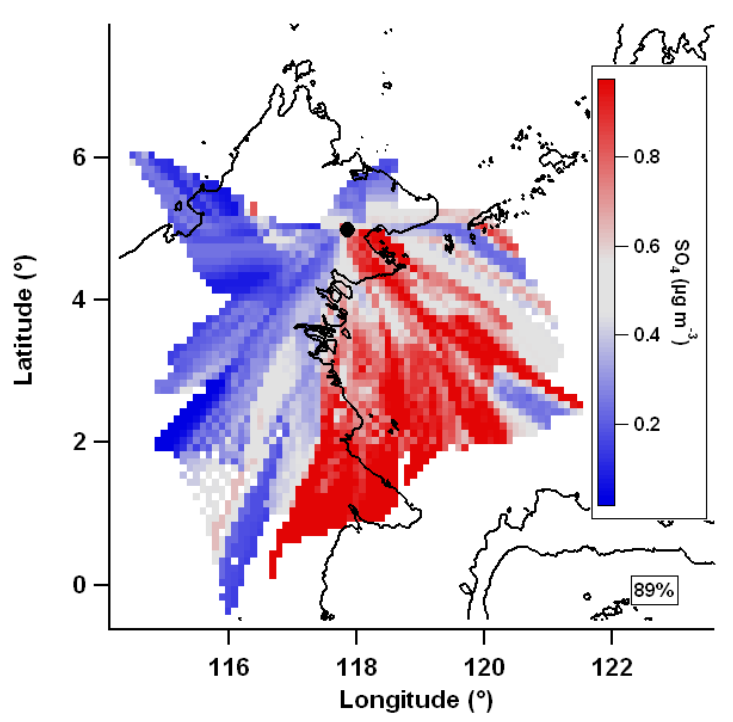

Fig. 15. Sulphate mean value map. Grey is median value, red is greater than median, blue is less than median and white denotes no data coverage. $36 \mathrm{~h}$ trajectories are used.

the Marine, Coastal and North-easterly clusters. These points show generally higher oxidation. This is consistent with an internally mixed regional background that is removed through wet deposition in inland Borneo. It is possible that the aerosol associated with line B could be sulphate from similar sources to that associated with line A, but with $\mathrm{OA}$ mass added during transit over conurbations on the east coast of Borneo, however this is not likely given the high level of OA oxidation which suggests long atmospheric lifetime, and the lack of association with individual cities. Most likely, 


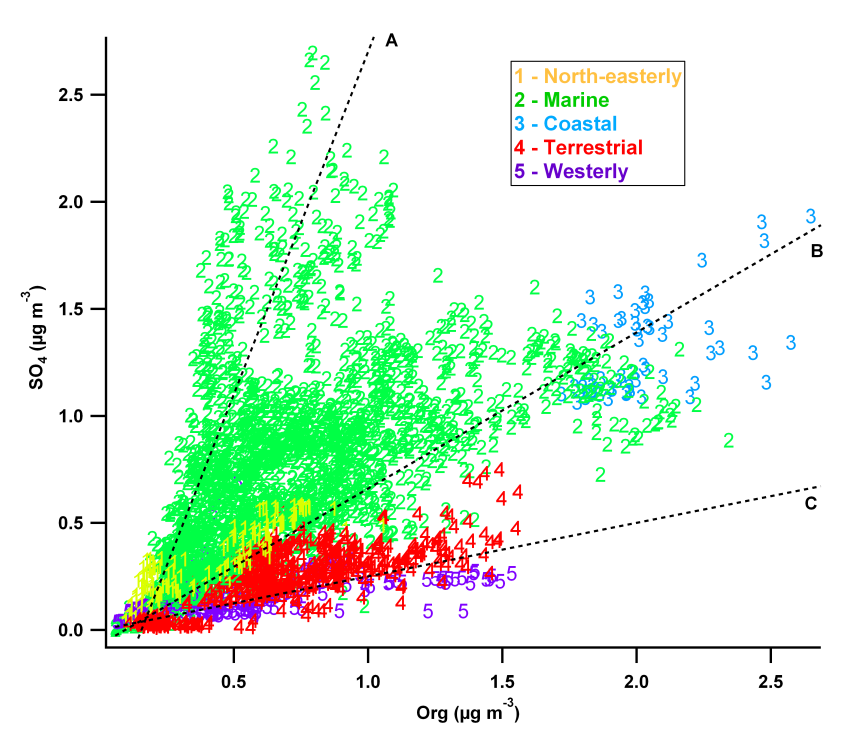

Fig. 16. $\mathrm{SO}_{4}$ loading vs. OA loading coloured and numbered by cluster. Lines, labelled with letters, indicate different proposed dependencies. Lines represent modes of the $\mathrm{SO}_{4}$ :org ratio histogram of values.

the aerosol whose sulphate and organic mass correlate along line B result from long range transport, which may well be a combination of anthropogenic and biogenic sources. Biogenic sources of organic matter are most likely to be of terrestrial origin and those of sulphate are likely to be marine in nature.

Line $\mathrm{C}$ indicates points of high OA loading with a weaker dependence on sulphate loading, which are characteristically associated with the Terrestrial and Westerly clusters. They show a range of levels of OA oxidation. This is consistent with biogenic production of SOA, providing a mixture of more and less aged OA.

For the region including the measurement site and the sea to the south-east, where the majority of sulphate containing air masses came from: DMS emissions from phytoplankton are predicted to contribute around 30-40\% of total column sulphate (Gondwe, 2003; Kloster et al., 2006); around $40-50 \%$ of surface sulphate is predicted to be from anthropogenic emissions (Tsai et al., 2010) with $<10 \%$ of surface sulphate concentrations predicted to be from shipping emissions (Capaldo et al., 1999); and around $30 \%$ of surface sulphate predicted from volcanic emissions (Graf et al., 1997).

It is likely that the apparent elevated sulphate loadings over the oil palms to the south-east of the site are mainly due to the preceding transport of the air across marine source regions. There may also be elevated sulphate loadings due to the proximity of marine sources such as DMS production and shipping as well as an increased anthropogenic influence. The fact that sulphate and ammonium loadings are depleted inland is probably due to the wet removal of the aerosols as they are transported through these regions of enhanced precipitation (Fig. 7).

\subsection{Combustion emissions}

High aerosol loadings at the beginning of the measurement period are associated with air masses from the south of the measurement site. This can be seen by splitting the data set into two periods of interest (POI): POI1 before 00:01 a.m. 29 June 2008 UTC and POI2 after. This point was chosen because of the drop in both organic and inorganic aerosol loadings and is indicated in Fig. 10. POI1 was influenced by air from the east coast of Borneo, and experienced greater amounts of OA (1.34 vs. $\left.0.62 \mu \mathrm{g} \mathrm{m}^{-3}\right)$, OOA1 (0.76 vs. $\left.0.27 \mu_{g^{-3}}\right)^{-}$, CO (177 vs. $98 \mathrm{ppb}$; Fig. 17), BC (0.36 vs. $0.18 \mu \mathrm{g} \mathrm{m}^{-3}$; Fig. 18$)$ and $91 \mathrm{Fac}\left(0.15\right.$ vs. $0.12 \mu \mathrm{g} \mathrm{m}^{-3}$; Fig. 19) than POI2. These quantities are all indicative of pollution. The $91 \mathrm{Fac}$ factor may suggesting biomass burning specifically due to its resemblance to previously reported biomass burning spectra (Alfarra et al., 2007; Allan et al., 2010), although it is a minor factor making up only $18 \%$ of total OA mass over the whole project. Trajectories also tended to be influenced by air masses that have higher maximum altitudes during POI1 compared to POI2, with median minimum trajectory pressures of $880 \mathrm{hPa}$ vs. $946 \mathrm{hPa}$ and tenth percentile pressures of $653 \mathrm{hPa}$ vs. $886 \mathrm{hPa}$, respectively.

During POI2, CO and 91Fac show strongly on-island sources implying that biomass burning still influences the site, albeit to a lesser extent. It is less evident that an onisland source of $\mathrm{BC}$ dominates during POI2, with elevated amounts to the south, both on and off-island. There is a disparity between inland $\mathrm{BC}$ and $\mathrm{CO}$ measurements during POI2, with the dominant $\mathrm{CO}$ source being inland and the dominant $\mathrm{BC}$ source being more coastal and marine. This would be explained if the $\mathrm{BC}$ and $\mathrm{CO}$ were emitted from biomass burning on the south coast of Borneo (or even further upwind) and then transported across the island. The BC would be depleted inland through wet removal but the $\mathrm{CO}$ concentrations would be largely unaffected. Any BC from shipping off the east coast that was insignificant compared to biomass burning emissions in POI1 would then be apparent in POI2. Modelled loadings of BC $\left(0.2-0.5 \mu \mathrm{g} \mathrm{m}^{-3}\right.$ for the region; Koch et al., 2009) are consistent with the BC equivalent loadings for POI1 and POI2.

The MODIS fire count shows more open fire activity on Borneo at the beginning of the campaign, with an average of 42 events per day in POI1 compared to 10 in POI2. The fires are mainly confined to the coast with particularly high activity on the south-west of the island. This is also true of the wider region as a whole, with an average of 193 events per day in POI1 compared to 176 in POI2 (for the region shown in Fig. 9). This is consistent with POI1 being particularly heavily influenced by aged biomass burning in the region, either transport of aged off-island biomass burning emissions, 
(a)

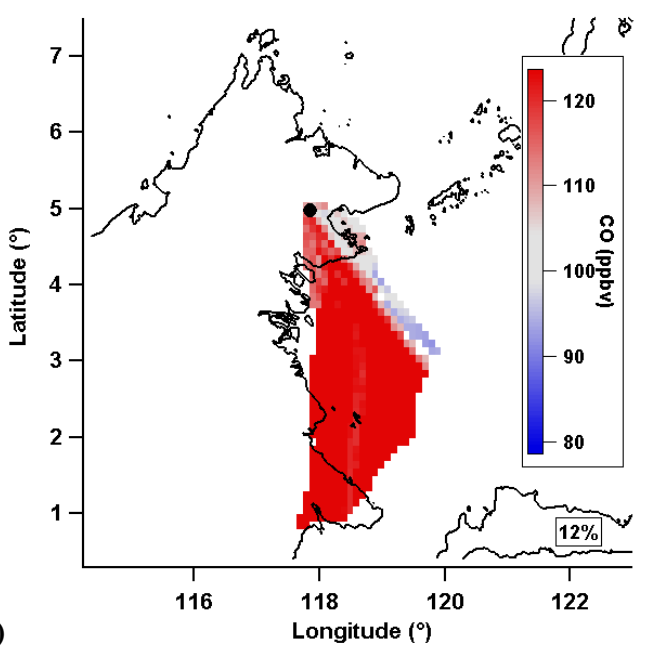

(b)

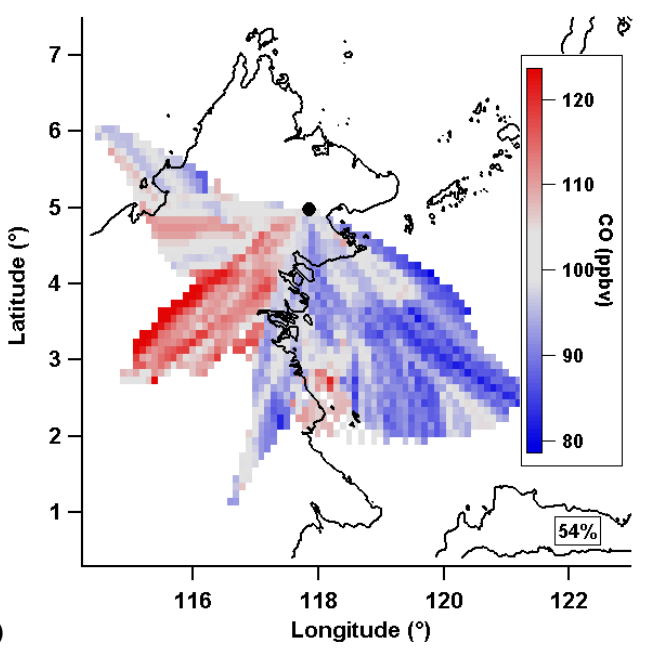

Fig. 17. Mean value maps of $\mathrm{CO}$ during (a) POI 1 and (b) POI 2. Colour scale is centred round the median value of the $\mathrm{CO}$ mean value map for the whole campaign.

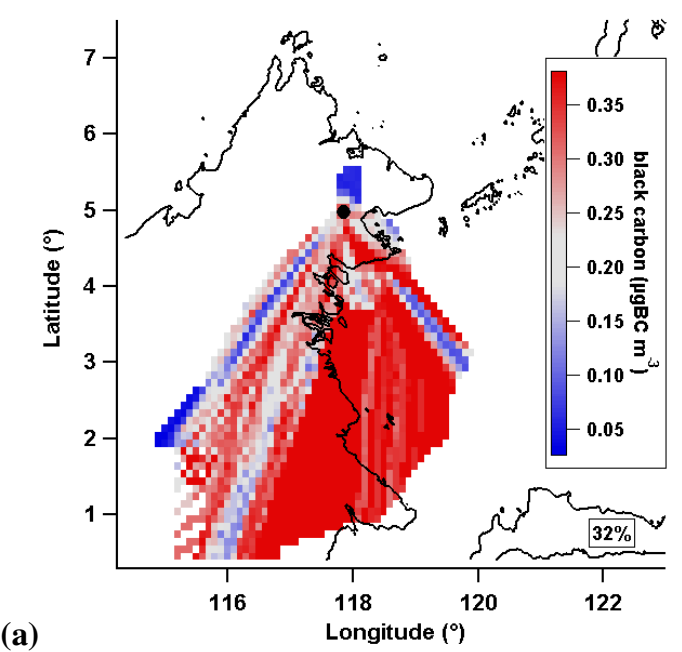

(a)

Fig. 18. Mean value maps of aerosol absorbance (expressed as black carbon equivalent loading) during (a) POI 1 and (b) POI 2. The colour scale is centred round the median value of the $\mathrm{BC}$ mean value map for the whole campaign.

or more local on-island biomass burning emissions. It is also the case that air masses during POI1 descended from higher altitudes than POI2, with mean minimum pressures of $838 \mathrm{hPa}$ and $931 \mathrm{hPa}$ and tenth percentile values of $652 \mathrm{hPa}$ and $886 \mathrm{hPa}$, respectively. The introduction of free tropospheric air may increase the dominance of biomass burning species which are likely to be transported from their source to the upper troposphere by pyroconvection.

It is possible that there is an oxidised aerosol influence from the south eastern coast of the island, particularly during POI1. The enhanced OOA1 loadings during POI1 may be due to processed emissions from biomass burning. In POI2 the majority of oxidised aerosol is in air masses external to the island, implying long range transport of OA. Taking this into consideration, it is likely that the OOA 1 in POI1 is from a combination of long range transport of OA and on-island production and ageing of biomass burning OA. Further separation of these sources during POI1 is not possible given the short time scale and small range of trajectories sampled.

The inorganic aerosol components and 82Fac are also all greater in POI1 than POI2. There has been some evidence in the literature that sulphate gases produced from biomass burning can condense onto biomass burning aerosol downwind of fires, so this could be a potential sulphate source (Gao et al., 2003). However, coastal and marine air masses dominate POI1 compared to POI2, which has a more balanced mixture of coastal/marine and inland air masses. This would explain the greater inorganic loadings in POI1, as 


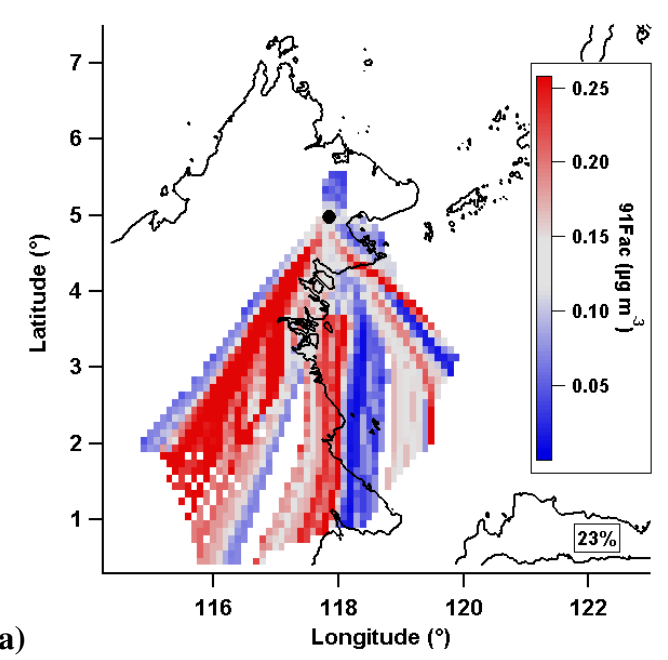

(a)

Fig. 19. Mean value maps of $91 \mathrm{Fac}$ during (a) POI 1 and (b) POI 2. Colour scale is the consistent between plots and is centred round the median value of the $91 \mathrm{Fac}$ mean value map for the whole campaign.

these aerosols are thought to be marine in origin (sulphate and chloride) or formed by reaction with marine aerosol (ammonium and nitrate). While $82 \mathrm{Fac}$ is not thought to be marine in origin, it is associated with marine air masses as these pass over the oil palm plantation to the south east of the site. It can also be speculated that some other controlling factor involved in the $82 \mathrm{Fac}$ OA was increased during POI1 (e.g. sulphate aerosol acidity or oxidation rates). Acidic sulphate has previously been shown to affect isoprene SOA formation and (Slowik et al., 2011) also showed their $\mathrm{m} / \mathrm{z} 82$ containing PMF factor may be associated with elevated sulphate concentrations. However, it appears that $82 \mathrm{Fac}$ shows little relation to the biomass burning markers throughout the project, suggesting that the increase during POI1 is unrelated to biomass burning. OOA 2 showed a very slight decrease in loadings between POI1 and POI2 (0.09 vs. $0.08 \mu \mathrm{g} \mathrm{m}^{-3}$ ), however this change is so small as to be within the uncertainty of the instrument and analysis methods.

\subsection{Dependence of hygroscopicity on regional source}

Figure 20 shows mean value maps of hygroscopicity measurements for two given aerosol sizes. These are representative of other measured sizes, with an average $r=0.9$ for six sizes between 32 and $258 \mathrm{~nm}$ for the $\mathrm{GF}_{90}$ mean value maps and an average $r=0.7$ for ten sizes between 57 and $202 \mathrm{~nm}$ for the $\mathrm{SS}_{\text {crit }}$ mean value map. A complete discussion of aerosol hygroscopicity and its relation to composition and size is detailed in Irwin et al. (2010). The subsaturated growth factor (between 0 and $90 \%$ relative humidity; $\mathrm{GF}_{90}$ ) shows good separation between terrestrial and marine air masses for both sizes, with higher aerosol $\mathrm{GF}_{90}$ measured in air of marine origin. Critical supersaturation (SS $\left.\mathrm{S}_{\text {crit }}\right)$ shows highest values from the south-west and east over Bongao island $\left(5^{\circ} \mathrm{N}, 120^{\circ} \mathrm{E}\right)$, which are air masses associated with low sulphate levels (Fig. 13) and less oxidised aerosol (Fig. 13). As previously stated, the AMS does not efficiently measure sea salt, however if primary externally mixed sea salt aerosol was present it would be expected to be apparent in HTDMA data as a population of particles with a high $(>2)$ growth factor in the upper dry size channels (Good et al., 2010a). Such a mode was not observed, justifying the comparison of AMS and hygroscopicity data. The hygroscopicity mean value maps are supported by the cluster averages. The hygroscopicity instruments have less data coverage than the AMS, not making measurements during the beginning of the measurement period when aerosol loadings were high in air mass from due south over the Sangkulirang Peninsula $\left(1^{\circ} \mathrm{N}, 117.5^{\circ} \mathrm{E}\right)$. Taking this into account, higher $\mathrm{GF}_{90}$ and lower $\mathrm{SS}_{\text {crit }}$ values are measured in air masses associated with higher ammonium sulphate mass fraction, and conversely lower $\mathrm{GF}_{90}$ and higher $\mathrm{SS}_{\text {crit }}$ values are measured in air mass associated with lower ammonium sulphate mass fraction. This is consistent with the literature which shows ammonium sulphate to be more hygroscopic than atmospheric OA in both sub- and supersaturated regimes (Petters and Kreidenweis, 2007; Swietlicki et al., 2008). If a single hygroscopicity parameter can be used to explain water uptake then GF and $\mathrm{SS}_{\text {crit }}$ mean value plots would be expected to anti-correlate. While there is generally good anti-correlation, there are some exceptions. These should be the subject of further investigation to establish if this is due merely to instrumental or inversion artifacts, or if it is indicative of limitations of single variable parameterisations (as discussed by Good et al., 2010b; Irwin et al., 2010). 


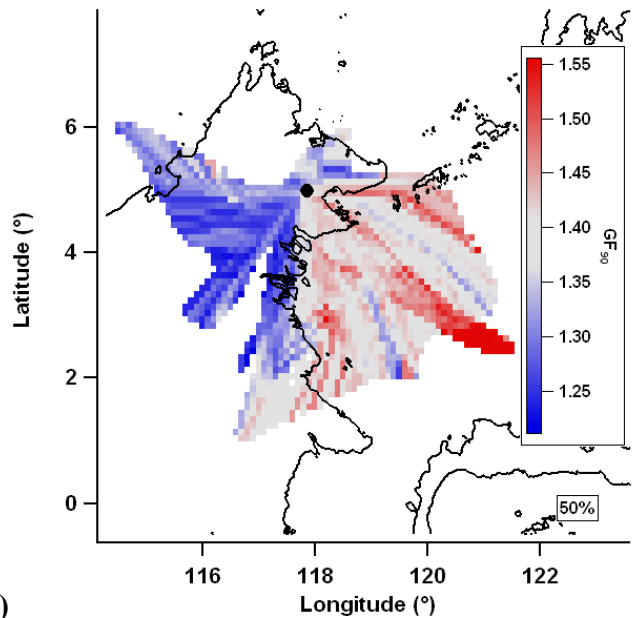

(a)

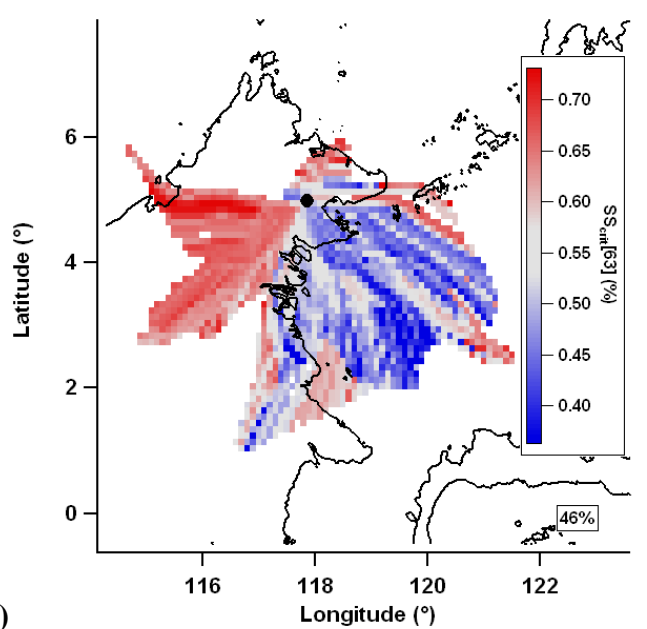

(b)

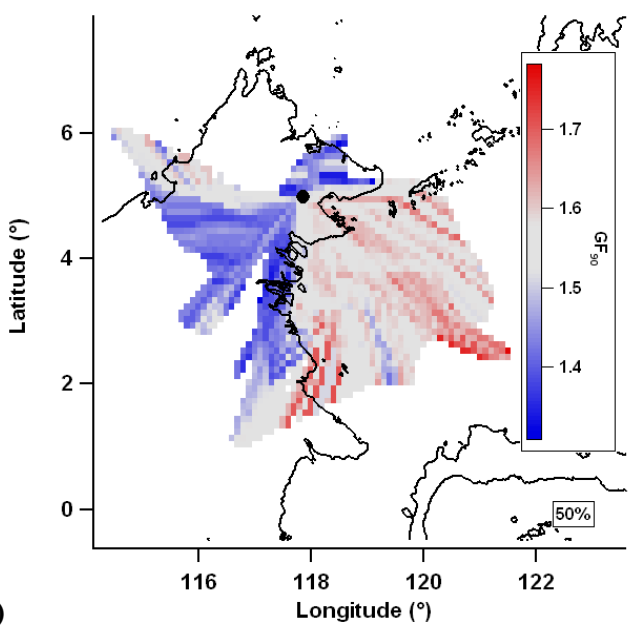

(d)

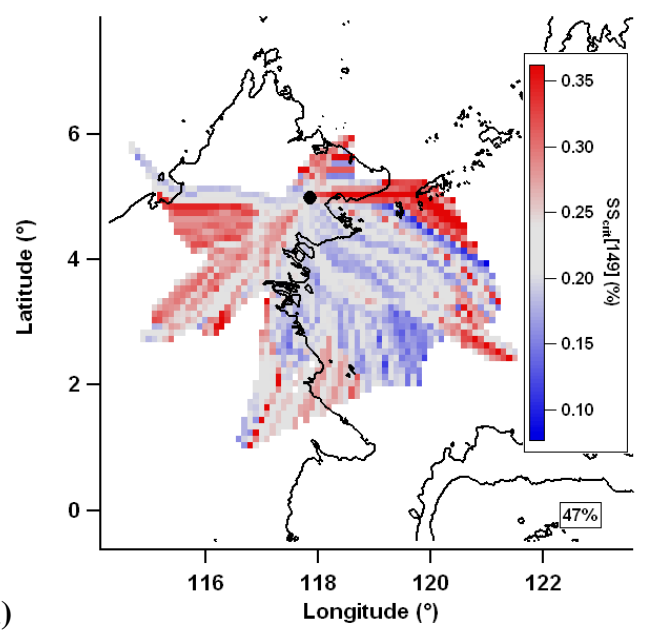

Fig. 20. Mean value maps of: sub-saturated growth factor for (a) $53 \mathrm{~nm}$ particles and (b) $155 \mathrm{~nm}$ particles; and critical supersaturation for (c) $63 \mathrm{~nm}$ particles and (d) $149 \mathrm{~nm}$ particles. Grey is median value, red is greater than median, blue is less than median and white denotes no data coverage. $36 \mathrm{~h}$ trajectories are used.

\section{Summary}

In general, many species demonstrated an association with either terrestrial or marine air masses. These are represented by data from the Terrestrial and Marine clusters which are displayed in Table 4. The analysis of halocarbons shows bromoform and dibromomethane to be strongly associated with coastal and marine air mass. These species are established marine tracers and this result provides validation for the back trajectory analysis presented here. Particularly high mixing ratios were observed in air masses associated with an area of seaweed cultivation directly east of the site. Methyl iodide was associated with similar air masses as the polybrominated compounds but it is unclear if it is produced from similar sources or by a different mechanism. It shows some departure from the polybrominated compounds, with inland levels not as uniformly low. Elevated inland values are also present in the methyl bromide mean value map. Methyl io- dide has previously been reported from terrestrial vegetation and soil as well as biomass burning, all of which may contribute to the inland sources. Biomass burning has been reported as a source of methyl bromide and there is some evidence for emission from tropical vegetation. In contrast to the other halocarbons, the methyl bromide mean value map showed low mixing ratios in air masses directly east of the site. There does seem to be some marine contribution, specifically from the coast directly south of the site. It also showed some elevated mixing ratios in air masses from directly north and south of the site. This may be due to biomass burning associated with the oil palm plantations however other biomass burning markers were not observed to be significant of this region. It could also be due to the proximity of coastal sources such as macro algae. It is unclear if the oil palms themselves are a source of methyl bromide. 
Table 4. Averages of data during $12 \mathrm{~h}$ periods classified as belonging to the Marine and Terrestrial clusters. Values quoted in the form mean (median 25 th \% \%ile $)$. Marine and Terrestrial data sets that are significantly different with a 95\% confidencelevel (using the two tailed Mann-Whitney U test (Cheung et al., 1997), which is nonparametric) are marked with an asterisk.

\begin{tabular}{|c|c|c|c|c|c|c|}
\hline & \multicolumn{3}{|c|}{ Borneo } & \multicolumn{3}{|c|}{ Amazonia } \\
\hline & Terrestrial & Marine & All & $\begin{array}{c}\text { In } \\
\text { basin }\end{array}$ & $\begin{array}{c}\text { Out of } \\
\text { basin }\end{array}$ & All \\
\hline Aerosol composition & & & & & & \\
\hline Organics $\left(\mu \mathrm{g} \mathrm{m}^{-3}\right)$ & $0.68\left(0.64_{0.47}^{0.89}\right)$ & $0.70\left(0.62_{0.41}^{0.90}\right)$ & $0.74\left(0.63_{0.43}^{0.95}\right)$ & 0.50 & 0.80 & 0.67 \\
\hline OOA $1 *\left(\mu \mathrm{g} \mathrm{m}^{-3}\right)$ & $0.29\left(0.25_{0.16}^{0.44}\right)$ & $0.33\left(0.27_{0.16}^{0.43}\right)$ & $0.35\left(0.27_{0.16}^{0.46}\right)$ & & & \\
\hline OOA $2 *\left(\mu \mathrm{g} \mathrm{m}^{-3}\right)$ & $0.11\left(0.10_{0.07}^{0.14}\right)$ & $0.07\left(0.07_{0.04}^{0.10}\right)$ & $0.08\left(0.07_{0.04}^{0.11}\right)$ & & & \\
\hline $82 \mathrm{Fac}^{*}\left(\mu \mathrm{g} \mathrm{m}^{-3}\right)$ & $0.12\left(0.09_{0.05}^{0.18}\right)$ & $0.18\left(0.14_{0.06}^{0.25}\right)$ & $0.18\left(0.13_{0.06}^{0.25}\right)$ & & & \\
\hline $91 \mathrm{Fac} *\left(\mu \mathrm{g} \mathrm{m}^{-3}\right)$ & $0.16\left(0.15_{0.09}^{0.21}\right)$ & $0.12\left(0.09_{0.05}^{0.15}\right)$ & $0.13\left(0.10_{0.05}^{0.17}\right)$ & & & \\
\hline Sulphate* $\left(\mu \mathrm{g} \mathrm{m}^{-3}\right)$ & $0.27\left(0.26_{0.19}^{0.35}\right)$ & $0.75\left(0.71_{0.40}^{0.99}\right)$ & $0.61\left(0.50_{0.28}^{0.89}\right)$ & 0.04 & 0.30 & 0.15 \\
\hline Ammonium* $\left(\mu \mathrm{g} \mathrm{m}^{-3}\right)$ & $0.09\left(0.09_{0.05}^{0.12}\right)$ & $0.25\left(0.24_{0.13}^{0.35}\right)$ & $0.21\left(0.19_{0.09}^{0.31}\right)$ & & & 0.02 \\
\hline Nitrate* $\left(\mu \mathrm{g} \mathrm{m}^{-3}\right)$ & $0.03\left(0.02_{0.01}^{0.04}\right)$ & $0.04\left(0.03_{0.02}^{0.05}\right)$ & $0.04\left(0.02_{0.01}^{0.05}\right)$ & & & 0.01 \\
\hline Chloride* $\left(\mu \mathrm{g} \mathrm{m}^{-3}\right)$ & $0.01\left(0.00_{0.00}^{0.01}\right)$ & $0.01\left(0.01_{0.00}^{0.01}\right)$ & $0.01\left(0.01_{0.00}^{0.01}\right)$ & & & 0.00 \\
\hline Absorbance* $\left(\mu \mathrm{g} \mathrm{m}^{-3}\right)$ & $0.19\left(0.16_{0.09}^{0.28}\right)$ & $0.21\left(0.17_{0.09}^{0.29}\right)$ & $0.22\left(0.18_{0.09}^{0.31}\right)$ & & & \\
\hline Hygroscopicity & & & & & & \\
\hline $\mathrm{GF}_{90} *[53 \mathrm{~nm}]$ & $1.30\left(1.29_{1.27}^{1.34}\right)$ & $1.42\left(1.41_{1.36}^{1.45}\right)$ & $1.38\left(1.38_{1.32}^{1.43}\right)$ & & & \\
\hline $\mathrm{GF}_{90} *[155 \mathrm{~nm}]$ & $1.46\left(1.49_{1.41}^{1.52}\right)$ & $1.58\left(1.58_{1.53}^{1.62}\right)$ & $1.53\left(1.54_{1.46}^{1.60}\right)$ & & & \\
\hline $\mathrm{SS}_{\mathrm{crit}} *[63 \mathrm{~nm}]$ & $0.63\left(0.63_{0.61}^{0.67}\right)$ & $0.48\left(0.47_{0.41}^{0.55}\right)$ & $0.53\left(0.54_{0.45}^{0.63}\right)$ & & & \\
\hline $\mathrm{SS}_{\text {crit }} *[149 \mathrm{~nm}]$ & $0.26\left(0.25_{0.18}^{0.31}\right)$ & $0.20\left(0.17_{0.15}^{0.23}\right)$ & $0.22\left(0.20_{0.16}^{0.27}\right)$ & & & \\
\hline Gas composition & & & & & & \\
\hline $\mathrm{CO} *(\mathrm{ppbv})$ & $111\left(110_{105}^{116}\right)$ & $98.4\left(94.3_{86.8}^{108}\right)$ & $101\left(100_{89.4}^{110}\right)$ & & & \\
\hline $\mathrm{CHBr}_{3} *$ (pptv) & $1.10\left(1.13_{0.96}^{1.28}\right)$ & $1.61\left(1.56_{1.38}^{1.79}\right)$ & $1.48\left(1.45_{1.17}^{1.75}\right)$ & & & \\
\hline $\mathrm{CH}_{2} \mathrm{Br}_{2} *$ (pptv) & $0.81\left(0.83_{0.80}^{0.85}\right)$ & $0.95\left(0.95_{0.91}^{0.99}\right)$ & $0.91\left(0.93_{0.85}^{0.98}\right)$ & & & \\
\hline $\mathrm{CH}_{3} \mathrm{I}^{*}$ (pptv) & $1.03\left(1.08_{0.97}^{1.12}\right)$ & $1.09\left(1.08_{0.99}^{1.18}\right)$ & $1.08\left(1.08_{0.99}^{1.18}\right)$ & & & \\
\hline $\mathrm{CH}_{3} \mathrm{Br}$ (pptv) & $6.73\left(6.68_{6.23}^{7.39}\right)$ & $6.92\left(6.90_{6.35}^{7.23}\right)$ & $6.80\left(6.69_{6.16}^{7.21}\right)$ & & & \\
\hline
\end{tabular}

Particulate nitrate and chloride show very similar time series trends and their mean value maps show their association with marine air. They exhibit a consistent diurnal profile with sharply elevated levels around midnight. Inspection of the AMS mass spectral information shows that the nitrate is unlikely to be present as ammonium nitrate or organic nitrates. The sea is an established source of sodium chloride aerosol, however this is not generally detected due to its slow vapourisation time in the AMS. Nitric acid may be produced by processing of biogenic $\mathrm{NO}_{\mathrm{x}}$ from soil (particularly from the fertilised oil palms plantations) and anthropogenic $\mathrm{NO}_{\mathrm{x}}$ emissions from settlements on the coast. This nitric acid could displace chloride from marine sodium chloride particles to give aqueous sodium nitrate aerosol that is more efficiently vapourised by the AMS than sodium chloride. It is likely that the liberated chloride is detected in the form of ammonium chloride although it is unclear if this is the case. The nocturnal profile may be caused by the reformation of nitrate and chloride aerosols in nocturnal fog droplets or their likely partitioning to the gas phase as the temperature increases during the day. It may also be associated with sampling of free tropospheric air when the boundary layer dropped below the measurement site, as was observed by LIDAR measurements (Pearson et al., 2010). While loadings of nitrate and chloride are small, they are higher than were measured in Amazonia which is consistent with greater influence of a marine source.

Levels of sulphate and ammonium are much higher than in the AMAZE-08 project in the rainforest of the Central Amazon basin where Chen et al. (2009) performed a similar analysis of sulphate and OA correlation to assess aerosol origin. This led to the classification of "in-basin" and "outof-basin" influences. $40 \%$ of the AMAZE-08 project was classified as being influenced by in-basin periods which were dominated by (relatively unoxidised) $\mathrm{OA}\left(0.5 \mu \mathrm{g} \mathrm{m}^{-3}\right)$, with 
little sulphate influence $\left(0.04 \mu \mathrm{g} \mathrm{m}^{-3}\right)$. These were deemed to be influenced mainly by BSOA freshly produced from rainforest VOC emissions. The out-of-basin periods, comprising $30 \%$ of the project, were less dominated by OA $\left(0.8 \mu \mathrm{g} \mathrm{m}^{-3}\right)$, which was more oxidised, with more sulphate influence $\left(0.3 \mu \mathrm{g} \mathrm{m}^{-3}\right)$. During these periods the measurement site was more influenced by long range transport of emissions from a variety of sources, probably processed DMS emissions from the Atlantic and biomass burning from West Africa. This is in contrast to Borneo which experienced much higher sulphate loadings $\left(0.61 \mu \mathrm{g} \mathrm{m}^{-3}\right)$. A study in West Africa measured similarly high levels of sulphate as were observed during OP3, which may be due to the marine influences during the West African monsoon phase.

Organic aerosol is most oxidised in marine air masses. Sulphate was associated with marine air masses and showed varying levels of correlation with organic aerosol. Sulphate unassociated with organic aerosol showed an off-island source and is likely to be mainly from the processing of marine DMS emissions. Air masses travelling over the mountainous interior of Borneo show depressed levels of regional background aerosol which is probably due to greater wet removal by orographically induced convective precipitation. These air masses are also associated with less oxygenated OA, presumably because the removal of regional aerosol increases the relative dominance of BSOA produced close to the measurement site. It should be noted that the sulphate loading in Terrestrial air masses (which are most representative of rainforest conditions) is even greater than the out-ofbasin classified data from Amazonia. This implies that, while regional aerosol is probably being depleted inland through wet deposition, a significant amount of aerosol is transported across the length of the island. Emissions from agriculture seemed to influence the site with isoprenoid BSOA showing elevated levels over the major oil palm plantations to the north and south of the site, which is consistent with measurements showing oil palm to emit five times as much isoprene as the natural rainforest (Hewitt et al., 2009).

OA associated with sulphate also showed an off-island source and an increased level of oxidation. This is likely to be long range transport of internally mixed aerosol. The sources are likely to be a combination of both anthropogenic and biogenic sources of both OA and sulphate but the OA has aged considerable during transport. It is unclear how much of this background signal is biogenic, anthropogenic or pyrogenic. It is also possible that the organic background may be wholly or in part due to marine biological sources (O'Dowd et al., 2004). A fraction of the OA showed only a weak association with sulphate. This predominantly arose during air periods influenced by on-island air masses and is likely to be biogenic aerosol from processing of VOCs emitted by the rainforest. Emissions from the rainforest in Borneo are likely to be measured at Bukit Atur as relatively fresh aerosol and so would be expected to be represented by OOA2 and $82 \mathrm{Fac}$, plus some fraction of OOA1. Considering only periods influenced by Terrestrial air masses, this gives an estimated loading of between 0.23 and $0.52 \mu \mathrm{g} \mathrm{m}^{-3}$, compared to $0.5 \mu \mathrm{g} \mathrm{m}^{-3}$ of OA seen in-basin in Amazonia. This lower contribution from the Bornean rainforest is likely to be mainly due to the difference in the size of the source regions.

The beginning of the campaign was dominated by high aerosol loadings, due in particular to sulphate and the organic OOA1 and 82Fac PMF factors. This period was also associated with increased CO, BC, 91Fac and all inorganic species. The MODIS satellite shows this to be a period of enhanced fire activity around the coast of Borneo, particularly on the southwest of the island. The beginning of the measurement period is influenced by coastal air running up the east coast of Borneo. It is likely that the increased biomass burning activity caused the increased $\mathrm{CO}, \mathrm{BC}$ and $91 \mathrm{Fac}$ loadings. It is also likely that processed organic biomass burning emissions contributed to the increased OOA 1 loadings. It is possible that some of the sulphate aerosol is from condensation of gases emitted from biomass burning. However, the correlation is not high $(r=0.45)$ between the OOA1 and sulphate time series during POI1 suggesting that, if this is occurring, it is a relatively small contribution. In addition to aerosol emissions from biomass burning, the enhanced inorganic and OOA1 aerosol loadings during POI 1 could be due to the dominance of coastal air, a reduction in precipitation causing less wet removal, or an increase in oxidation rates. The latter two could themselves be consequences of biomass burning emissions.

Aerosol hygroscopicity showed marked differences between terrestrial and marine air masses, however the data coverage does not include the period of more intense biomass burning. The most hygroscopic aerosol associated with the same air masses as high ammonium sulphate concentrations. As sulphate aerosol is more hygroscopic than (even highly oxidised) organic aerosol, the sulphate to organic mass ratio would be expected to be the driving factor in the aerosol hygroscopicity.

\section{Conclusions}

The results are consistent with a regional background of sulphate and aged organic aerosol that is removed by wet deposition in the interior of Borneo. This may be expected on an island, where off-island sources are likely to be distant enough to contribute to an aged background. Seven day air mass trajectories show the site was influenced by the least populated areas with the least amount of detected fires, when compared to the wider region. Given this it is likely that biological sources dominated the regional background.

Both the Marine and Terrestrial clusters had much higher sulphate loadings $\left(0.75\right.$ and $0.27 \mu \mathrm{g} \mathrm{m}^{-3}$, respectively) than were measured in Amazonia $\left(0.15 \mu \mathrm{g} \mathrm{m}^{-3}\right)$, which is probably due to a greater marine influence. The rainforest ecosystem has also been reported as a minor source 
of sulphur gases (and associated aerosol) in the Amazon (Andreae et al., 1990), but the analysis presented here shows if this is present it is a comparatively minor source, with Terrestrial air masses containing $65 \%$ less sulphate than Marine.

The sulphate appears to be largely neutralised to ammonium sulphate by time of arrival at the site, probably by terrestrial ammonium. The rainforest and oil palms appear to be sources of BSOA, with an estimated mean concentration of $0.26 \mu \mathrm{g} \mathrm{m}^{-3}$, however there are no periods where local BSOA dominates as was the case in the AMAZE-08 project. The region is influenced by some level of biomass burning, although, apart from the beginning of the measurement period, this appears to be a relatively minor source. Far field biomass burning emissions may be so aged as to be part of the regional background, however inspection of seven day back trajectories were not associated with areas of particularly high fire activity in the region. There also appears to be a minor influence at night from marine chloride reacting with terrestrial nitrate.

In general Borneo shows a wider range of influences than Amazonia. Despite data coverage lower than other comparable analyses the methods proved useful in assessing the origin of species measured. This study shows that the Amazon, whilst clearly an important part of the biosphere, is not representative of the tropics as a whole. The "maritime continent" region needs to be considered separately from the Amazon, as being a heterogeneous and complex mixture of biogenic, marine and anthropogenic influence.

\section{Supplementary material related to this article is available online at: http://www.atmos-chem-phys.net/11/9605/2011/ acp-11-9605-2011-supplement.pdf.}

Acknowledgements. Thanks to Gavin McMeeking (Colorado State University) and Mathew Evans (The University of Leeds) for useful conversations in the preparation of this manuscript. Thanks also to Minnie Wong (Fire Information and Resource Management System) for providing archived MODIS fire data. The OP3 project was funded by the UK Natural Environment Research Council [grant number NE/D002117/1]. We thank the Malaysian and Sabah Governments for their permission to conduct research in Malaysia; the Malaysian Meteorological Department (MMD) for access to the Bukit Atur Global Atmosphere Watch station and their long term ozone record; Leong Chow Peng (formerly of MMD) for her support in the early stages of the project; Waidi Sinun of Yayasan Sabah and his staff and Glen Reynolds of the Royal Society's South East Asian Rain Forest Research Programme and his staff for logistical support at the Danum Valley Field Centre; the NERC Facility for Ground-based Atmospheric Measurements and Halo Photonics for support with the LIDAR deployment; Phua Mui How of the University Malaysia Sabah for his help with the land cover map; and the rest of the OP3 project team for their individual and collective efforts. This is paper number 525 of the Royal Society's South East Asian Rainforest Research Programme.

Edited by: R. MacKenzie

\section{References}

Alfarra, M. R., Prevot, A. S. H., Szidat, S., Sandradewi, J., Weimer, S., Lanz, V. A., Schreiber, D., Mohr, M., and Baltensperger, U.: Identification of the mass spectral signature of organic aerosols from wood burning emissions, Environ. Sci. Technol., 41, 5770-5777, doi:10.1021/es062289b, 2007.

Allan, J. D., Bower, K. N., Coe, H., Boudries, H., Jayne, J. T., Canagaratna, M. R., Millet, D. B., Goldstein, A., Quinn, P. K., Weber, R. J., and Worsnop, D. R.: Submicron aerosol composition at Trinidad Head, California, during ITCT 2K2: its relationship with gas phase volatile organic carbon and assessment of instrument performance, J. Geophys. Res., 109, D23S24, doi:10.1029/2003JD004208, 2004.

Allan, J. D., Topping, D. O., Good, N., Irwin, M., Flynn, M., Williams, P. I., Coe, H., Baker, A. R., Martino, M., Niedermeier, N., Wiedensohler, A., Lehmann, S., Müller, K., Herrmann, H., and McFiggans, G.: Composition and properties of atmospheric particles in the eastern Atlantic and impacts on gas phase uptake rates, Atmos. Chem. Phys., 9, 9299-9314, doi:10.5194/acp-9-9299-2009, 2009.

Allan, J. D., Williams, P. I., Morgan, W. T., Martin, C. L., Flynn, M. J., Lee, J., Nemitz, E., Phillips, G. J., Gallagher, M. W., and Coe, H.: Contributions from transport, solid fuel burning and cooking to primary organic aerosols in two UK cities, Atmos. Chem. Phys., 10, 647-668, doi:10.5194/acp-10-647-2010, 2010.

Allen, A. G., Oppenheimer, M. F., Baxter, P. J., Horrocks, L. A., Galle, B., McGonigle, A. J. S., and Duffell, H. J.: Primary sulfate aerosol and associated emissions from Masaya Volcano, Nicaragua, J. Geophys. Res., 107, 4682, doi:10.1029/2002JD002120, 2002.

Andreae, M. O., Berresheiem, H., Bingemer, H., Jacob, D. J., Lewis, B. L., Li, S.-M., and Talbot, R. W.: The atmospheric sulfur cycle over the Amazon Basin. II. Wet season, J. Geophys. Res., 95, 16813-16824, doi:10.1029/JD095iD10p16813, 1990.

Ashbaugh, L.: A residence time probability analysis of sulfur concentrations at grand Canyon National Park, Atmos. Environ., 19, 1263-1270, doi:10.1016/0004-6981(85)90256-2, 1985.

Avissar, R., Silva Dias, P., Silva Dias, M., and Nobre, C. A.: The Large-Scale Biosphere-Atmosphere Experiment in Amazonia (LBA): insights and future research needs, J. Geophys. Res., 107, 8086, doi:10.1029/2002JD002704, 2002.

British Atmospheric Data Centre: European Centre for MediumRange Weather Forecasts back trajectories, http://badc.nerc.ac. uk/data/ecmwf-op/ (last access: January 2010), 2006a.

British Atmospheric Data Centre: European Centre for Medium-Range Weather Forecasts. ECMWF Operational Analysis data, http://badc.nerc.ac.uk/view/badc.nerc.ac. uk_ATOM_dataent_ECMWF-OP (last access: October 2010), $2006 \mathrm{~b}$.

Baker, J.: Emissions of $\mathrm{CH}_{3} \mathrm{Br}$, organochlorines, and organoiodines from temperate macroalgae, Glob. Change Sci., 3, 93-106, doi:10.1016/S1465-9972(00)00021-0, 2001.

Bassford, M. R., Nickless, G., Simmonds, P. G., Lewis, A. C., Pilling, M. J., and Evans, M. J.: The concurrent observation of methyl iodide and dimethyl sulphide in marine air; implications for sources of atmospheric methyl iodide, Atmos. Environ., 33, 2373-2383, doi:10.1016/S1352-2310(98)00403-8, 1999.

Bates, T. S., Calhoun, J. A., and Quinn, P. K.: Variations in the methanesulfonate to sulfate molar ratio in submicrometer marine 
aerosol particles over the South Pacific Ocean, J. Geophys. Res., 95, 813-816, 1992.

Bell, N., Hsu, L., Jacob, M., Schultz, M. G., Blake, D. R., Butler, J. H., King, D. B., Lobert, J. M., and Maier-Reimer, E.: Methyl iodide: atmospheric budget and use as a tracer of marine convection in global models, J. Geophys. Res., 107, 4340, doi:10.1029/2001JD001151, 2002.

Blei, E., Hardacre, C. J., Mills, G. P., Heal, K. V., and Heal, M. R.: Identification and quantification of methyl halide sources in a lowland tropical rainforest, Atmos. Environ., 44, 1005-1010, doi:10.1016/j.atmosenv.2009.12.023, 2010.

Butler, J. H., King, D. B., Lobert, J. M., Montzka, S. A., YvonLewis, S. A., Hall, B. D., Warwick, N. J., Mondeel, D. J., Aydin, M., and Elkins, J. W.: Oceanic distributions and emissions of short-lived halocarbons, Global Biogeochem. Cy., 21, GB1023, doi:10.1029/2006GB002732, 2007.

Canagaratna, M. R., Jayne, J. T., Jimenez, J. L., Allan, J. D., Alfarra, M. R., Zhang, Q., Onasch, T. B., Drewnick, F., Coe, H., Middlebrook, A., Delia, A., Williams, L. R., Trimborn, A. M., Northway, M. J., DeCarlo, P. F., Kolb, C. E., Davidovits, P., and Worsnop, D. R.: Chemical and microphysical characterization of ambient aerosols with the aerodyne aerosol mass spectrometer., Mass Spectrom. Rev., 26, 185-222, doi:10.1002/mas.20115, 2007.

Capaldo, K., Corbett, J. J., Kasibhatla, P., Fischbeck, P., and Pandis, S. N.: Effects of ship emissions on sulphur cycling and radiative climate forcing over the ocean, Nature, 400, 743-746, doi:10.1038/23438, 1999.

Cape, J. N., Methven, J., and Hudson, L. E.: The use of trajectory cluster analysis to interpret trace gas measurements at Mace Head, Ireland, Atmos. Environ., 34, 3651-3663, doi:10.1016/S1352-2310(00)00098-4, 2000.

Capes, G., Johnson, B., McFiggans, G., Williams, P. I., Haywood, J., and Coe, H.: Aging of biomass burning aerosols over West Africa: aircraft measurements of chemical composition, microphysical properties, and emission ratios, J. Geophys. Res., 113, D00C15, doi:10.1029/2008JD009845, 2008.

Capes, G., Murphy, J. G., Reeves, C. E., McQuaid, J. B., Hamilton, J. F., Hopkins, J. R., Crosier, J., Williams, P. I., and Coe, H.: Secondary organic aerosol from biogenic VOCs over West Africa during AMMA, Atmos. Chem. Phys., 9, 3841-3850, doi:10.5194/acp-9-3841-2009, 2009.

Carpenter, L. J. and Liss, P. S.: On temperate sources of bromoform and other reactive organic bromine gases, J. Geophys. Res., 105, 20539-20547, doi:10.1029/2000JD900242, 2000.

Carter, C., Finley, W., Fry, J., Jackson, D., and Willis, L.: Palm oil markets and future supply, Eur. J. Lipid Science Technol., 109, 307-314, doi:10.1002/ejlt.200600256, 2007.

Chan, M. N., Surratt, J. D., Claeys, M., Edgerton, E. S., Tanner, R. L., Shaw, S. L., Zheng, M., Knipping, E. M., Eddingsaas, N. C., Wennberg, P. O., and Seinfeld, J. H.: Characterization and quantification of isoprene-derived epoxydiols in ambient aerosol in the Southeastern United States, Environ. Sci. Technol., 44, 4590-4596, 2010.

Chen, Q., Farmer, D. K., Schneider, J., Zorn, S. R., Heald, C. L., Karl, T. G., Guenther, A., Allan, J. D., Robinson, N., Coe, H., Kimmel, J. R., Pauliquevis, T., Borrmann, S., Pöschl, U., Andreae, M. O., Artaxo, P., Jimenez, J. L., and Martin, S. T.: Mass spectral characterization of submicron biogenic organic parti- cles in the Amazon Basin, Geophys. Res. Lett., 36, L20806, doi:10.1029/2009GL039880, 2009.

Cheung, Y. K., and Klot, J. H.: The Mann Whitney Wilcoxon Distribution Using Linked Lists, Statistica Sinica, 7, 805-813, 1997.

Claeys, M., Graham, B., Vas, G., Wang, W., Vermeylen, R., Pashynska, V., Cafmeyer, J., Guyon, P., Andreae, M. O., Artaxo, P., and Maenhaut, W.: Formation of secondary organic aerosols through photooxidation of isoprene, Science, 303(5661), 11731176, doi:10.1126/science.1092805, 2004.

Cox, M. L., Sturrock, G. A., Fraser, P. J., Siems, S. T., and Krummel, P. B.: Identification of regional sources of methyl bromide and methyl iodide from AGAGE observations at Cape Grim, Tasmania, J. Atmos. Chem., 50, 59-77, doi:10.1007/s10874-0052434-5, 2005.

Cross, E., Slowik, J., Davidovits, P., Allan, J., Worsnop, D., Jayne, J., Lewis, D., Canagaratna, M., and Onasch, T.: Laboratory and ambient particle density determinations using light scattering in conjunction with aerosol mass spectrometry, Aerosol Sci. Technol., 41, 343-359, doi:10.1080/02786820701199736, 2007.

Cubison, M., Coe, H., and Gysel, M.: A modified hygroscopic tandem DMA and a data retrieval method based on optimal estimation, J. Aerosol Sci., 36, 846-865, doi:10.1016/j.jaerosci.2004.11.009, 2005.

Davies, D. K., Ilavajhala, S., Wong, M. M., and Justice, C. O.: Fire information for resource management system: archiving and distributing MODIS active fire data, IEEE Trans. Geosci. Remote S., 47, 72-79, doi:10.1109/TGRS.2008.2002076, 2009.

DeCarlo, P. F., Kimmel, J. R., Trimborn, A., Northway, M. J., Jayne, J. T., Aiken, A. C., Gonin, M., Fuhrer, K., Horvath, T., Docherty, K. S., Worsnop, D. R., and Jimenez, J. L.: Fielddeployable, high-resolution, time-of-flight aerosol mass spectrometer, Anal. Chem., 78, 8281-8289, 2006.

Denman, K., Brasseur, G., Chidthaisong, A., Ciais, P., Cox, P., Dickinson, R., Hauglustaine, D., Heinze, C., Holland, E., Jacob, D., Lohmann, U., Ramachandran, S., Dias, P. D. S., Wofsy, S., and Zhang, X.: Couplings Between Changes in the Climate System and Biogeochemistry, Chap. Couplings, Cambridge University Press, Cambridge, UK and New York, NY, USA, 2007.

Facchini, M. C., Decesari, S., Rinaldi, M., Carbone, C., Finessi, E., Mircea, M., Fuzzi, S., Moretti, F., Tagliavini, E., Ceburnis, D., and O'Dowd, C. D.: Important source of marine secondary organic aerosol from biogenic amines, Environ. Sci. Technol., 42, 9116-9121, doi:10.1021/es8018385, 2008.

Farmer, D. K., Matsunaga, A., Docherty, K. S., Surratt, J. D., Seinfeld, J. H., Ziemann, P. J., and Jimenez, J. L.: Response of an aerosol mass spectrometer to organonitrates and organosulfates and implications for atmospheric chemistry, P. Natl. Acad. Sci USA, 107, 6670-6675, doi:10.1073/pnas.0912340107, 2010.

Food and Agriculture Organisation: Global Forest Resources Assessment 2010: Main Report, Bernan Assoc, Rome, http://books. google.com/books? id=vEcJTwEACAAJ $\backslash$ \&pgis=1 (last access: January 2011), 2010.

Froyd, K. D., Murphy, S. M., Murphy, D. M., de Gouw, J. A., Eddingsaas, N. C., and Wennberg, P. O.: Contribution of isoprene-derived organosulfates to free tropospheric aerosol mass., P. Natl. Acad. Sci. USA, 107, 21360-21365, 
doi:10.1073/pnas.1012561107, 2010.

Gao, S., Hegg, D. A., Hobbs, P. V., Kirchstetter, T. W., Magi, B. I., and Sadilek, M.: Water-soluble organic components in aerosols associated with savanna fires in Southern Africa: identification, evolution, and distribution, J. Geophys. Res., 108, 8491, doi:10.1029/2002JD002324, 2003.

Gerbig, C., Schmitgen, S., Kley, D., Volz-Thomas, A., Dewey, K., and Haaks, D.: An improved fast-response vacuum-UV resonance fluorescence CO instrument, J. Geophys. Res., 104, 16991704, doi:10.1029/1998JD100031, 1999.

Giglio, L.: An enhanced contextual fire detection algorithm for MODIS, Remote Sens. Environ., 87, 273-282, doi:10.1016/S0034-4257(03)00184-6, 2003.

Gondwe, M.: The contribution of ocean-leaving DMS to the global atmospheric burdens of DMS, MSA, $\mathrm{SO}_{2}$, and $\mathrm{NSS} \mathrm{SO}_{4}^{=}$, Global Biogeochem. Cy., 17, 1056, doi:10.1029/2002GB001937, 2003.

Good, N., Topping, D. O., Allan, J. D., Flynn, M., Fuentes, E., Irwin, M., Williams, P. I., Coe, H., and McFiggans, G.: Consistency between parameterisations of aerosol hygroscopicity and CCN activity during the RHaMBLe discovery cruise, Atmos. Chem. Phys., 10, 3189-3203, doi:10.5194/acp-10-3189-2010, 2010a.

Good, N., Topping, D. O., Duplissy, J., Gysel, M., Meyer, N. K., Metzger, A., Turner, S. F., Baltensperger, U., Ristovski, Z., Weingartner, E., Coe, H., and McFiggans, G.: Widening the gap between measurement and modelling of secondary organic aerosol properties?, Atmos. Chem. Phys., 10, 2577-2593, doi:10.5194/acp-10-2577-2010, 2010 b.

Goodwin, K. D., North, W. J., and Lidstrom, M. E.: Production of bromoform and dibromomethane by giant kelp: factors affecting release and comparison to anthropogenic bromine sources, Limnol. Oceanogr., 42, 1725-1734, 1997.

Graf, H.-F., Feichter, J., and Langmann, B.: Volcanic sulfur emissions: estimates of source strength and its contribution to the global sulfate distribution, J. Geophys. Res., 102, 10727-10738, doi:10.1029/96JD03265, 1997.

Gysel, M., McFiggans, G., and Coe, H.: Inversion of tandem differential mobility analyser (TDMA) measurements, J. Aerosol Sci., 40, 134-151, doi:10.1016/j.jaerosci.2008.07.013, 2009.

Hewitt, C. N., MacKenzie, A. R., Di Carlo, P., Di Marco, C. F., Dorsey, J. R., Evans, M., Fowler, D., Gallagher, M. W., Hopkins, J. R., Jones, C. E., Langford, B., Lee, J. D., Lewis, A. C., Lim, S. F., McQuaid, J., Misztal, P., Moller, S. J., Monks, P. S., Nemitz, E., Oram, D. E., Owen, S. M., Phillips, G. J., Pugh, T. A. M., Pyle, J. A., Reeves, C. E., Ryder, J., Siong, J., Skiba, U., and Stewart, D. J.: Nitrogen management is essential to prevent tropical oil palm plantations from causing groundlevel ozone pollution., P. Natl. Acad. Sci. USA, 106, 1844718451, doi:10.1073/pnas.0907541106, 2009.

Hewitt, C. N., Lee, J. D., MacKenzie, A. R., Barkley, M. P., Carslaw, N., Carver, G. D., Chappell, N. A., Coe, H., Collier, C., Commane, R., Davies, F., Davison, B., DiCarlo, P., Di Marco, C. F., Dorsey, J. R., Edwards, P. M., Evans, M. J., Fowler, D., Furneaux, K. L., Gallagher, M., Guenther, A., Heard, D. E., Helfter, C., Hopkins, J., Ingham, T., Irwin, M., Jones, C., Karunaharan, A., Langford, B., Lewis, A. C., Lim, S. F., MacDonald, S. M., Mahajan, A. S., Malpass, S., McFiggans, G., Mills, G., Misztal, P., Moller, S., Monks, P. S., Nemitz, E., Nicolas-Perea, V., Oetjen, H., Oram, D. E., Palmer, P. I.,
Phillips, G. J., Pike, R., Plane, J. M. C., Pugh, T., Pyle, J. A., Reeves, C. E., Robinson, N. H., Stewart, D., Stone, D., Whalley, L. K., and Yin, X.: Overview: oxidant and particle photochemical processes above a south-east Asian tropical rainforest (the OP3 project): introduction, rationale, location characteristics and tools, Atmos. Chem. Phys., 10, 169-199, doi:10.5194/acp-10-169-2010, 2010.

International Fuel Quality Center: International Desil Rankings - Top 100 Sulphur, http://www.ifqc.org/UserFiles/file/Misc/ DieselRankings0909(1).pdf, (last access: April 2010), 2009.

Irwin, M., Good, N., Crosier, J., Choularton, T. W., and McFiggans, G.: Reconciliation of measurements of hygroscopic growth and critical supersaturation of aerosol particles in central Germany, Atmos. Chem. Phys., 10, 11737-11752, doi:10.5194/acp10-11737-2010, 2010.

Irwin, M., Robinson, N., Allan, J. D., Coe, H., and McFiggans, G.: Size-resolved aerosol water uptake and cloud condensation nuclei measurements as measured above a Southeast Asian rainforest during OP3, Atmos. Chem. Phys. Discuss., 11, 3117-3159, doi:10.5194/acpd-11-3117-2011, 2011.

Jimenez, J. L., Canagaratna, M. R., Donahue, N. M., Prevot, A. S. H., Zhang, Q., Kroll, J. H., DeCarlo, P. F., Allan, J. D., Coe, H., Ng, N. L., Aiken, A. C., Docherty, K. S., Ulbrich, I. M., Grieshop, A. P., Robinson, A. L., Duplissy, J., Smith, J. D., Wilson, K. R., Lanz, V. A., Hueglin, C., Sun, Y. L., Tian, J., Laaksonen, A., Raatikainen, T., Rautiainen, J., Vaattovaara, P., Ehn, M., Kulmala, M., Tomlinson, J. M., Collins, D. R., Cubison, M. J., Dunlea, E. J., Huffman, J. A., Onasch, T. B., Alfarra, M. R., Williams, P. I., Bower, K. N., Kondo, Y., Schneider, J., Drewnick, F., Borrmann, S., Weimer, S., Demerjian, K., Salcedo, D., Cottrell, L., Griffin, R., Takami, A., Miyoshi, T., Hatakeyama, S., Shimono, A., Sun, J. Y., Zhang, Y. M., Dzepina, K., Kimmel, J. R., Sueper, D., Jayne, J. T., Herndon, S. C., Trimborn, A. M., Williams, L. R., Wood, E. C., Middlebrook, A. M., Kolb, C. E., Baltensperger, U., and Worsnop, D. R.: Evolution of organic aerosols in the atmosphere, Science, 326, 1525-1529, doi:10.1126/science.1180353, 2009.

Jordan, T., Seen, A., and Jacobsen, G.: Levoglucosan as an atmospheric tracer for woodsmoke, Atmos. Environ., 40, 5316-5321, doi:10.1016/j.atmosenv.2006.03.023, 2006.

Justice, C., Giglio, L., Korontzi, S., Owens, J., Morisette, J., Roy, D., Descloitres, J., Alleaume, S., Petitcolin, F., and Kaufman, Y.: The MODIS fire products, Remote Sens. Environ., 83, 244-262, 2002.

Kalkstein, L. S., Tan, G., and Skindlov, J. A.: An evaluation of three clustering procedures for use in synoptic climatological classification, J. Appl. Meteorol., 26, 717-730, 1987.

Kleindienst, T. E., Lewandowski, M., Offenberg, J. H., Jaoui, M., and Edney, E. O.: The formation of secondary organic aerosol from the isoprene $+\mathrm{OH}$ reaction in the absence of $\mathrm{NO}_{\mathrm{x}}$, Atmos. Chem. Phys., 9, 6541-6558, doi:10.5194/acp-9-6541-2009, 2009.

Kloster, S., Feichter, J., Maier-Reimer, E., Six, K. D., Stier, P., and Wetzel, P.: DMS cycle in the marine ocean-atmosphere system a global model study, Biogeosciences, 3, 29-51, doi:10.5194/bg3-29-2006, 2006.

Koch, D., Schulz, M., Kinne, S., McNaughton, C., Spackman, J. R., Balkanski, Y., Bauer, S., Berntsen, T., Bond, T. C., Boucher, O., Chin, M., Clarke, A., De Luca, N., Dentener, F., Diehl, T., 
Dubovik, O., Easter, R., Fahey, D. W., Feichter, J., Fillmore, D., Freitag, S., Ghan, S., Ginoux, P., Gong, S., Horowitz, L., Iversen, T., Kirkevåg, A., Klimont, Z., Kondo, Y., Krol, M., Liu, X., Miller, R., Montanaro, V., Moteki, N., Myhre, G., Penner, J. E., Perlwitz, J., Pitari, G., Reddy, S., Sahu, L., Sakamoto, H., Schuster, G., Schwarz, J. P., Seland, Ø., Stier, P., Takegawa, N., Takemura, T., Textor, C., van Aardenne, J. A., and Zhao, Y.: Evaluation of black carbon estimations in global aerosol models, Atmos. Chem. Phys., 9, 9001-9026, doi:10.5194/acp-9-9001-2009, 2009.

Laboratory Earth Systems Research Global Monitoring Division: NOAA Calibration Scales for Various Trace Gases, http://www. esrl.noaa.gov/gmd/ccl/scales.html (last access: August 2008), 2008.

Lance, S., Medina, J., Smith, J. N., and Nenes, A.: Mapping the operation of the DMT continuous flow CCN counter, Aerosol Sci. Technol., 40, 242-254, 2006.

Lanz, V. A., Alfarra, M. R., Baltensperger, U., Buchmann, B., Hueglin, C., and Prévôt, A. S. H.: Source apportionment of submicron organic aerosols at an urban site by factor analytical modelling of aerosol mass spectra, Atmos. Chem. Phys., 7, 15031522, doi:10.5194/acp-7-1503-2007, 2007.

Lebel, T., Parker, D. J., Flamant, C., Bourlès, B., Marticorena, B., Mougin, E., Peugeot, C., Diedhiou, A., Haywood, J. M., Ngamini, J. B., Polcher, J., Redelsperger, J.-L., and Thorncroft, C. D.: The AMMA field campaigns: multiscale and multidisciplinary observations in the West African region, Q. J. Roy. Meteor. Soc., 136, 8-33, doi:10.1002/qj.486, 2010.

Lim, Y. B. and Ziemann, P. J.: Kinetics of the heterogeneous conversion of 1,4-hydroxycarbonyls to cyclic hemiacetals and dihydrofurans on organic aerosol particles., Phys. Chem. Chem. Phys., 11, 8029-8039, doi:10.1039/b904333k, 2009.

Manley, S. L., Goodwin, K., and North, W. J.: Laboratory production of bromoform, methylene bromide, and methyl iodide by macroalgae and distribution in nearshore Southern California waters, Limnol. Oceanogr., 37, 1652-1659, 1992.

Martin, S. T., Andreae, M. O., Althausen, D., Artaxo, P., Baars, H., Borrmann, S., Chen, Q., Farmer, D. K., Guenther, A., Gunthe, S. S., Jimenez, J. L., Karl, T., Longo, K., Manzi, A., Müller, T., Pauliquevis, T., Petters, M. D., Prenni, A. J., Pöschl, U., Rizzo, L. V., Schneider, J., Smith, J. N., Swietlicki, E., Tota, J., Wang, J., Wiedensohler, A., and Zorn, S. R.: An overview of the Amazonian Aerosol Characterization Experiment 2008 (AMAZE-08), Atmos. Chem. Phys., 10, 1141511438, doi:10.5194/acp-10-11415-2010, 2010.

Matthew, B., Middlebrook, A., and Onasch, T.: Collection efficiencies in an aerodyne aerosol mass spectrometer as a function of particle phase for laboratory generated aerosols, Aerosol Sci. Technol., 42, 884-898, doi:10.1080/02786820802356797, 2008.

McFiggans, G., Alfarra, M. R., Allan, J., Bower, K., Coe, H., Cubison, M., Topping, D., Williams, P., Decesari, S., Facchini, C., and Fuzzi, S.: Simplification of the representation of the organic component of atmospheric particulates, Faraday Discuss., 130, 341, 341-362, doi:10.1039/b419435g, 2005.

McMorrow, J. and Talip, M. A.: Decline of forest area in Sabah, Malaysia: relationship to state policies, land code and land capability, Global Environ. Change, 11, 217-230, doi:10.1016/S0959-3780(00)00059-5, 2001.

Mead, M., Khan, M., White, I., Nickless, G., and Shall- cross, D.: Methyl halide emission estimates from domestic biomass burning in Africa, Atmos. Environ., 42, 5241-5250, doi:10.1016/j.atmosenv.2008.02.066, 2008.

Millero, F. J.: The physical chemistry of seawater, Annu. Rev. Earth Planet. Sci., 2, 101-150, doi:10.1146/annurev.ea.02.050174.000533, 1974.

Morgan, W. T., Allan, J. D., Bower, K. N., Capes, G., Crosier, J., Williams, P. I., and Coe, H.: Vertical distribution of sub-micron aerosol chemical composition from North-Western Europe and the North-East Atlantic, Atmos. Chem. Phys., 9, 5389-5401, doi:10.5194/acp-9-5389-2009, 2009.

Morgan, W. T., Allan, J. D., Bower, K. N., Highwood, E. J., Liu, D., McMeeking, G. R., Northway, M. J., Williams, P. I., Krejci, R., and Coe, H.: Airborne measurements of the spatial distribution of aerosol chemical composition across Europe and evolution of the organic fraction, Atmos. Chem. Phys., 10, 4065-4083, doi:10.5194/acp-10-4065-2010, 2010.

Ng, N. L., Canagaratna, M. R., Zhang, Q., Jimenez, J. L., Tian, J., Ulbrich, I. M., Kroll, J. H., Docherty, K. S., Chhabra, P. S., Bahreini, R., Murphy, S. M., Seinfeld, J. H., Hildebrandt, L., Donahue, N. M., DeCarlo, P. F., Lanz, V. A., Prévôt, A. S. H., Dinar, E., Rudich, Y., and Worsnop, D. R.: Organic aerosol components observed in Northern Hemispheric datasets from Aerosol Mass Spectrometry, Atmos. Chem. Phys., 10, 46254641, doi:10.5194/acp-10-4625-2010, 2010.

Newton, H. M., Reeves, C. E., Mills, G. P., and Oram D. E.: Organohalogens in and above the rainforest of Borneo, to be submitted to Atmos. Chem. Phys., 2011.

Novakov, T., Corrigan, C., Penner, J., Chuang, C., Rosaria, O., and Bracero, O. M.: Organic aerosols in the Caribbean trade winds: a natural source?, J. Geophys. Res.-Atmos., 102, 21307-21313, 1997.

O’Dowd, C. D., Facchini, M. C., Cavalli, F., Ceburnis, D., Mircea, M., Decesari, S., Fuzzi, S., Yoon, Y. J., and Putaud, J.P.: Biogenically driven organic contribution to marine aerosol, Nature, 431, 676-680, 2004.

Paatero, P.: Least squares formulation of robust non-negative factor analysis, Chemometr. Intell. Lab., 37, 23-35, doi:10.1016/S0169-7439(96)00044-5, 1997.

Paatero, P. and Tapper, U.: Positive matrix factorization: a non-negative factor model with optimal utilization of error estimates of data values, Environmetrics, 5, 111-126, doi:10.1002/env.3170050203, 1994.

Pandis, S. N., Wexler, A. S., and Seinfeld, J. H.: Dynamics of tropospheric aerosols, J. Phys. Chem., 99, 9646-9659, doi:10.1021/j100024a003, 1995.

Paulot, F., Crounse, J. D., Kjaergaard, H. G., Kürten, A., St. Clair, J. M., Seinfeld, J. H., and Wennberg, P. O.: Unexpected epoxide formation in the gas-phase photooxidation of isoprene., Science, 325, 730-733, doi:10.1126/science.1172910, 2009.

Pearson, G., Davies, F., and Collier, C.: Remote sensing of the tropical rain forest boundary layer using pulsed Doppler lidar, Atmos. Chem. Phys., 10, 5891-5901, doi:10.5194/acp-10-58912010, 2010.

Petters, M. D. and Kreidenweis, S. M.: A single parameter representation of hygroscopic growth and cloud condensation nucleus activity, Atmos. Chem. Phys., 7, 1961-1971, doi:10.5194/acp-71961-2007, 2007.

Petzold, A. and Schonlinner, M.: Multi-angle absorption photome- 
ter - a new method for the measurement of aerosol light absorption and atmospheric black carbon, J. Aerosol Sci., 35, 421-441, doi:10.1016/j.jaerosci.2003.09.005, 2004.

Quack, B., Peeken, I., Petrick, G., and Nachtigall, K.: Oceanic distribution and sources of bromoform and dibromomethane in the Mauritanian upwelling, J. Geophys. Res., 112, C10006, doi:10.1029/2006JC003803, 2007.

Reeves, C. E.: Atmospheric budget implications of the temporal and spatial trends in methyl bromide concentration, J. Geophys. Res., 108, 4343, doi:10.1029/2002JD002943, 2003.

Roberts, G. and Nenes, A.: A continuous-flow streamwise thermalgradient CCN chamber for atmospheric measurements, Aerosol Sci. Technol., 39, 206-221, doi:10.1080/027868290913988, 2005.

Robinson, N. H., Hamilton, J. F., Allan, J. D., Langford, B., Oram, D. E., Chen, Q., Docherty, K., Farmer, D. K., Jimenez, J. L., Ward, M. W., Hewitt, C. N., Barley, M. H., Jenkin, M. E., Rickard, A. R., Martin, S. T., McFiggans, G., and Coe, H.: Evidence for a significant proportion of Secondary Organic Aerosol from isoprene above a maritime tropical forest, Atmos. Chem. Phys., 11, 1039-1050, doi:10.5194/acp-11-10392011, 2011.

Rollins, A. W., Fry, J. L., Hunter, J. F., Kroll, J. H., Worsnop, D. R., Singaram, S. W., and Cohen, R. C.: Elemental analysis of aerosol organic nitrates with electron ionization highresolution mass spectrometry, Atmos. Meas. Tech., 3, 301-310, doi:10.5194/amt-3-301-2010, 2010.

Simoneit, B., Schauer, J. J., Nolte, C. G., Oros, D. R., Elias, V. O., Fraser, M. P., Rogge, W. F., and Cass, G. R.: Levoglucosan, a tracer for cellulose in biomass burning and atmospheric particles, Atmos. Environ., 33, 173-182, doi:10.1016/S13522310(98)00145-9, 1999.

Sive, B. C., Varner, R. K., Mao, H., Blake, D. R., Wingenter, O. W., and Talbot, R.: A large terrestrial source of methyl iodide, Geophys. Res. Lett., 34, L17808, doi:10.1029/2007GL030528, 2007.

Slowik, J. G., Brook, J., Chang, R. Y.-W., Evans, G. J., Hayden, K., Jeong, C.-H., Li, S.-M., Liggio, J., Liu, P. S. K., McGuire, M., Mihele, C., Sjostedt, S., Vlasenko, A., and Abbatt, J. P. D.: Photochemical processing of organic aerosol at nearby continental sites: contrast between urban plumes and regional aerosol, Atmos. Chem. Phys., 11, 2991-3006, doi:10.5194/acp-11-29912011, 2011.

Smythe-Wright, D., Boswell, S. M., Breithaupt, P., Davidson, R. D., Dimmer, C. H., and Eiras Diaz, L. B.: Methyl iodide production in the ocean: implications for climate change, Global Biogeochem. Cy., 20, GB3003, doi:10.1029/2005GB002642, 2006.

Surratt, J. D., Murphy, S. M., Kroll, J. H., Ng, N. L., Hildebrandt, L., Sorooshian, A., Szmigielski, R., Vermeylen, R., Maenhaut, W., Claeys, M., Flagan, R. C., and Seinfeld, J. H.: Chemical composition of secondary organic aerosol formed from the photooxidation of isoprene, J. Phys. Chem. A, 110, 9665-9690, 2006

Surratt, J. D., Gomez-Gonzalez, Y., Chan, A. W. H., Vermeylen, R., Shahgholi, M., Kleindienst, T. E., Edney, E. O., Offenberg, J. H., Lewandowski, M., Jaoui, M., Maenhaut, W., Claeys, M., Flagan, R. C., and Seinfeld, J. H.: Organosulfate formation in biogenic secondary organic aerosol, J. Phys. Chem. A, 112, 83458378, doi:10.1021/jp802310p, 2008.

Surratt, J. D., Chan, A. W. H., Eddingsaas, N. C., Chan, M., Loza, C. L., Kwan, A. J., Hersey, S. P., Flagan, R. C.,
Wennberg, P. O., and Seinfeld, J. H.: Atmospheric chemistry special feature: reactive intermediates revealed in secondary organic aerosol formation from isoprene., P. Natl. Acad. Sci. USA, 15, 6640-6645, doi:10.1073/pnas.0911114107, 2010.

Swietlicki, E., Hansson, H.-C., Hameri, K., Svenningsson, B., Massling, A., McFiggans, G., McMurry, P. H., Petaja, T., Tunved, P., Gysel, M., Topping, D., Weingartner, E., Baltensperger, U., Rissler, J., Wiedensohler, A., and Kulmala, M.: Hygroscopic properties of submicrometer atmospheric aerosol particles measured with H-TDMA instruments in various environments - a review, Tellus B, 60, 432-469, doi:10.1111/j.16000889.2008.00350.x, 2008.

Tsai, I.-C., Chen, J.-P., Lin, P.-Y., Wang, W.-C., and Isaksen, I. S. A.: Sulfur cycle and sulfate radiative forcing simulated from a coupled global climate-chemistry model, Atmos. Chem. Phys., 10, 3693-3709, doi:10.5194/acp-10-3693-2010, 2010.

Ulbrich, I. M., Canagaratna, M. R., Zhang, Q., Worsnop, D. R., and Jimenez, J. L.: Interpretation of organic components from Positive Matrix Factorization of aerosol mass spectrometric data, Atmos. Chem. Phys., 9, 2891-2918, doi:10.5194/acp-9-2891-2009, 2009.

Venzke, E., Wunderman, R. W., McClelland, L., Simkin, T., Luhr, J. F., Siebert, L., and Mayberry, G. (Eds.): Global Volcanism, 1968 to the Present, Smithsonian Institution, Global Volcanism Program Digital Information Series, GVP-4, http://www. volcano.si.edu/reports/ (last access: February 2009), 2010.

Williams, I., Gallagher, M. W., Choularton, T. W., Coe, H., Bower, K. N., and McFiggans, G.: Aerosol development and interaction in an urban plume, Aerosol Sci. Technol., 32, 120-126, doi:10.1080/027868200303821, 2000.

Williams, P. I., McFiggans, G., and Gallagher, M. W.: Latitudinal aerosol size distribution variation in the Eastern Atlantic Ocean measured aboard the FS-Polarstern, Atmos. Chem. Phys., 7, 2563-2573, doi:10.5194/acp-7-2563-2007, 2007.

Winklmayr, W., Reischl, G. P., Lindner, A. O., and Berner, A.: A new electromobility spectrometer for the measurement of aerosol size distributions in the size range from 1 to $1000 \mathrm{~nm}$, J. Aerosol Sci., 22, 289-296, 1991.

Worton, D. R., Mills, G. P., Oram, D. E., and Sturges, W. T.: Gas chromatography negative ion chemical ionization mass spectrometry: application to the detection of alkyl nitrates and halocarbons in the atmosphere, J. Chromatogr. A, 1201, 112-119, 2008.

Yokouchi, Y., Hasebe, F., Fujiwara, M., Takashima, H., Shiotani, M., Nishi, N., Kanaya, Y., Hashimoto, S., Fraser, P., Toom-Sauntry, D., Mukai, H., and Nojiri, Y.: Correlations and emission ratios among bromoform, dibromochloromethane, and dibromomethane in the atmosphere, J. Geophys. Res., 110, D23309, doi:10.1029/2005JD006303, 2005.

Zhang, Q., Jimenez, J. L., Canagaratna, M. R., Allan, J. D., Coe, H., Ulbrich, I., Alfarra, M. R., Takami, A., Middlebrook, A. M., Sun, Y. L., Dzepina, K., Dunlea, E., Docherty, K., DeCarlo, P. F., Salcedo, D., Onasch, T. B., Jayne, J. T., Miyoshi, T., Shimono, A., Hatakeyama, S., Takegawa, N., Kondo, Y., Schneider, J., Drewnick, F., Borrmann, S., Weimer, S., Demerjian, K., Williams, P., Bower, K. N., Bahreini, R., Cottrell, L., Griffin, R. J., Rautiainen, J., Sun, J. Y., Zhang, Y. M., and Worsnop, D. R.: Ubiquity and dominance of oxygenated species in organic aerosols in anthropogenically-influenced Northern 
Hemisphere midlatitudes, Geophys. Res. Lett., 34, 101029, doi:10.1029/2007GL029979, 2007.

Zhou, Y., Mao, H., Russo, R. S., Blake, D. R., Wingenter, O. W., Haase, K. B., Ambrose, J., Varner, R. K., Talbot, R., and Sive, B. C.: Bromoform and dibromomethane measurements in the seacoast region of New Hampshire, 2002-2004, J. Geophys. Res., 113, D08305, doi:10.1029/2007JD009103, 2008.
Zorn, S. R., Drewnick, F., Schott, M., Hoffmann, T., and Borrmann, S.: Characterization of the South Atlantic marine boundary layer aerosol using an aerodyne aerosol mass spectrometer, Atmos. Chem. Phys., 8, 4711-4728, doi:10.5194/acp-8-47112008, 2008. 